\title{
『現代日本語書き言葉均衡コーパス』に基づく 指標比喻データベース
}

\author{
加藤 祥 $\dagger$ ・菊地 礼 ${ }^{\dagger \dagger} \cdot$ 浅原 正幸 ${ }^{\dagger \dagger}$
}

日本語の比喻表現の実態把握を目的として, 『現代日本語書き言葉均衡コーパス』に 基づく指標比喻データベースを構築した。『比喻表現の理論と分類』に掲載されてい る 359 種類の比喻指標要素を手掛かりとし, 『分類語彙表』に基ついて類義用例を確 認しながら指標比喻表現候補を展開し，コアデータ 6 レジスタ（Yahoo!知恵袋・白 書・Yahoo!ブログ・書籍・雑誌・新聞） $1,290,060$ 語から人手で 822 件抽出した。抽 出した比喻用例には, 喻辞・被喻辞の情報と, その分類語彙表番号を付与したほか,

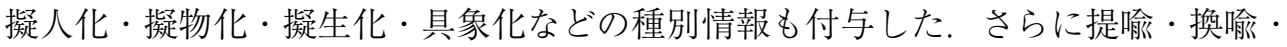
文脈比喻・慣用表現などの情報も付与した。 上記作業は言語学者によったが, 非専 門家が比喻表現をどのように捉えるかを評価するために，比喻性・新奇性・わかり やすさ・擬人化・具体化 (具象化) の 5つの観点について，1事例あたり 22-77人 分 (平均 33 人分) の評定值を付与した。 レジスタ毎の相対度数や評定值の分布によ り，現代日本語の指標比喻表現の使用傾向を確認した

キーワード : 直喻・比喻表現・比喻指標・語義タグ付きコーパス

\section{Database of Figurative Expressions with Indicators from the 'Balanced Corpus of Contemporary Written Japanese'}

\author{
Sachi $\mathrm{Kato}^{\dagger}$, Rei Kikuchi ${ }^{\dagger \dagger}$ and Masayuki Asahara ${ }^{\dagger \dagger}$
}

\begin{abstract}
A figurative expression database was constructed based on the Balanced Corpus of Contemporary Written Japanese (BCCWJ), with the goal of understanding actual usage of figurative expressions in Japanese. Using the three hundred fifty nine types of figurative expression indicators listed in 'A Stylistic Study of the Figurative' (Hiyuhyogen-no Riron-to Bunrui) as clues for metaphor indicator elements, candidates were selected based on synonym examples confirmed in the 'Word List by Semantic Principles', and a total of eight hundred twenty two expressions were manually extracted from one million two hundred ninety thousand sixty words found in six registers of core data (Yahoo! Answers, white papers; Yahoo! Blog, books, magazines, and newspapers). In addition to the vehicle, topic, and Word List by Semantic Principles label of each metaphor example, type categories such as personification, objectifi-
\end{abstract}

\footnotetext{
† 目白大学, Mejiro University

†† 中央大学, Chuo University

†† 人間文化研究機構 国立国語研究所, NINJAL, Japan
} 
cation, biomimicry, and substantiation were defined. Examples were also classified into categories such as synecdoche, metonymy, contextual metaphor, and idiomatic expression. Although the work above was carried out by linguists, ratings were also assigned to each example for five aspects (figurativeness, novelty, comprehensibility, personification, and substantiation) based on evaluations by twenty two to seventy seven non-experts (average: thirty three) to evaluate how these figurative expressions were perceived. The usage trends for each of these figurative expression indicators in contemporary Japanese were determined based on their relative frequency in each register and distribution of their rating values.

Key Words: Simile, Figurative Expression, Metaphor Indicator, Sense Tagged Corpus

\section{1 はじめに}

比喻表現は, 意味解釈の構成性の要請を満たさない事例の代表である. Lakoff and Johnson (1980)（日本語訳 (レイコフ，ジョンソン 1986)）は「思考過程の大部分が比喻によって成り立 つ」と言及している。言語学においても，そもそも形態や語彙，辞書構造，文法をはじめ，言 語の大部分が比喻的な性質に基づくとされ, 比喻研究は「言語の伝達のメカニズムを理解して いくための基礎的な研究」と位置づけられる (山梨 1988). また, 言語処理においても基本義 からの転換という現象が意味処理の技術的障壁になっている，比喻表現データベースは，言語 学・言語処理の双方で求められている重要な言語資源である。そこで我々は, 『現代日本語書 き言葉コーパス』(Maekawa, Yamazaki, Ogiso, Maruyama, Ogura, Kashino, Koiso, Yamaguchi, Tanaka, and Den 2014)（以下 BCCWJ と呼ぶ）コアデータ 1,290,060 語 57,256 文に基づく大規 模比喻表現データベースを構築した.

比喻性の判断は, 受容主体の主観によるものであり, 形式意味論的な妥当性・健全性を保持しうる ものではない，我々は，研究対象となる比喻表現が適切に含まれるような作業手順として MIP (Metaphor Identification Procedure) (Pragglejaz Group 2007) を拡張した MIPVU (Metaphor Identification Procedure VU University Amsterdam) (Steen, Dorst, Herrmann, Kaal, Krennmayr, and Pasma 2010) を取り入れる.さらに, 安定的に一貫して抽出するため, 先行研究の中でもより形 式的に比喻を捉える中村 (1977)の研究に倣い, 喩辞（喻える表現）の基本義からの語義の転換 ・ 逸脱と喻辞に関連する要素の結合に着目する。喻辞の語義の転換・逸脱の判断には, 『分類語彙 表』(国立国語研究所 2004) に基ついた語義を用い, 被喻辞（喻えられる表現）との語義の差異 を検討する ${ }^{1}$.さらに, 被喻辞相当の語義があるべき箇所に喻辞の語義が現れる表現中の要素の 結合における比喻的な転換・逸脱の有無を確認する。比喻表現と考えられる部分について，喩

1 本稿では, 喻える表現・語を「喻辞」, 喻えられる表現・語を「被喻辞」と呼ぶ，それぞれ，「喻詞」と「被喻詞」， 「ソース (source)」と「ターゲット (target)」,「サキ」と「モト」,「媒体 (vehicle)」と「主題 (topic)」と呼ばれる ものに相当する。 
辞相当の出現箇所を同定するともに，比喻関連情報をアノテーションする．但し，非専門家が 比喻表現と認識しない表現を多く含む結果となるため, 非専門家の判断としてクラウドソーシ ングによる比喻性の判断を収集する。

我々が構築した指標比喻データベースは，以下のもので構成される：

- 比喻表現該当部 (3.4 節)

- 比喻指標要素とその類型 (中村 1977) (3.2 節), その分類語彙表番号 (3.2 節, 3.3 節)

- 比喻的転換に関わる要素の結合とその類型 (3.2 節), その分類語彙表番号 (3.3 節)

・ 概念マッピングにおける喻辞・被喻辞 (3.5 節), その分類語彙表番号 (3.3 節)

・概念マッピングに基づく比喻種別（擬人・擬生など）（3.5 節）

- 非専門家の評定值（比喻性・新奇性・わかりやすさ・擬人化・具体化）(3.6 節).

本稿では，そのデータ整備作業の概要を示すとともに構築したデータベースの基礎統計や用 例を示す，本研究の貢献は次の通りである。まず，BCCWJコアデータ 6 レジスタ（Yahoo!知 恵袋・白書・Yahoo!ブログ・書籍・雑誌・新聞） 1,290,060 語 57,256 文に基づく，日本語の大規 模指標比喻データベースを構築した。この指標比喻データベース構築において，まず英語で実 施された比喻用例収集手法である MIP, MIPVU に対して『分類語彙表』の語義に基づく手法を 提案し, 日本語の比喻用例収集作業手順を整理した。本作業に必要な比喻用例収集の手掛かり となる中村 (1977) の比喻指標要素（359 種類）を電子化し，新たに分類語彙表番号を付与し, 再利用可能な比喻指標要素データベースを整備した。また，収集した比喻表現に対し，喻辞・ 被喻辞・分類語彙表番号・比喻種別などをアノテーションした。さらに，収集した指標比喻を 刺激としてクラウドソーシングによる質問紙調査を実施し, 非専門家の比喻性判断を収集した. 構築した大規模指標比喻データベースに基づく調査が可能となったため, 比喻表現の遍在性を 確認し，非専門家の比喻性判断の実態を明らかにした。

本稿の構成は次のとおりである．2 節に関連研究を示す． 3 節ではデー夕整備の概要について 解説する．4 節ではデータの集計を行い，指標比喻の分布を概観する．5節にまとめと今後の方 向性について示す.

\section{2 関連研究}

以下では, 比喻表現コーパス・比喻表現用例集の先行研究について確認する。 2.1 節では, 英 語に関する先行研究として Amsterdam Metaphor Corpus (Steen et al. 2010) とその作業手順で ある Metaphor Identification Procedure (MIP) (Pragglejaz Group 2007) について解説する. 2.2 節では, 我々の研究の基底となる中村 (1977)の『比喻表現理論と分類』における日本語の比喻 表現の定義について示す。 2.3 節では, その他の日本語の比喻表現コーパスおよび比喻表現用例 集について示す. 


\subsection{Amsterdam Metaphor Corpus とその作業手順 MIP}

英語における大規模な比喻コーパスの先行研究として, Amsterdam Metaphor Corpus (Steen et al. 2010) がある. BNC-Baby コーパスから抽出した 4 レジスタ約 19 万語を用い, 隠喻 (indirect) と直喻 (direct), 暗黙 (implicit)の 3 種類の比喻の関連語を検索可能にしたもので, MIP (Metaphor Identification Procedure) (Pragglejaz Group 2007) を拡張したMIPVU (Metaphor Identification Procedure VU University Amsterdam) ${ }^{2}$ (Steen et al. 2010)により, 語単位の比喻性が判定され, 直喻の指標 (metaphor signals) と概念マッピング (conceptual mappings) 情報が付与されている.

図 1 にMIPの概要（著者訳）(Pragglejaz Group 2007) を示す。テキストを読んで，テキスト の文脈内における語義を判定し，基本義からの転換を認識する作業手順であるが，語義の判定 基準および基本義の定義などは言語依存であろう。3.1節では，この MIP に基づく日本語の比 喻表現収集手順の概要を図 1 に対応する形で示す.

MIPVU は MIP が認定する比喻表現を直喻や境界事例にも拡張したものである。図 2 に MIPVUによる MIP の拡張（著者訳）(Steen et al. 2010)を示す. 比喻表現と見なす収集対象 として，隠喻のみならず，直喻や比喻の境界事例を含む。語義の典拠として，主に Macmillan Dictionary 3 を用い, Macmillan Dictionary では判断できない場合に, Longman Dictionary of

（1）テキストの文脈全体を読み，意味の一般的な解釈を規定する.

(2) テキストの文脈における語彙単位を決定する.

(3)

(a) テキストの各語彙単位について, 文脈におけるその意味, つまり，テキストに喚起されるシチュ エーション（前後関係の意味）でそれが実体，関係，または属性にどのように適用されるかを規定 する．語彙単位の前後にくるものを考慮する.

(b) 各語彙単位について, 他の文脈では, 所定の文脈に比べてょり基本的な最新の意味を持つか否 かを決定する．我々の目的上，基本的意味の傾向は

- より具体的で，それらが喚起するものは，想像しやすく，見やすく，聞きやすく, 感じ取 りやすく，嗅ぎ取りやすく，味わいやすいものである.

- 身体的な動作に関連がある.

・より厳密（漠然としたものとは対照的に）である.

- 歴史的に古い.

基本的意味が, 必ずしも語菓単位で最も頻出する意味とは限らない.

(c) 語彙単位が他の文脈で所定の文脈に比べてより基本的な最新の意味を持つ場合, 前後関係の意 味は基本的意味と対照的でありながら，より理解されうるものなのか否かを決定する.

(4) そうであれば, その語彙単位を比喻的なものとしてマークする.

図 1 Metaphor Identification Procedure (MIP) の概要（著者訳）

\footnotetext{
${ }^{2}$ http://www.vismet.org/metcor/documentation/MIPVU.html

3 https://www.macmillandictionary.com/
} 
-（此喻表現は）（品詞などの）単語のクラスの境界は超えられない. 例えば, 動詞の前後関係の意 味は，名詞としてのその基本的意味と同等と見ない

-（その上で比喻表現としての抽出対象は）次のものを含む：

- 直喻

- 隠喻

- 比喻の境界事例

- 比喻のシグナル (指標・結合など $)$

- 擬人化のための比喻

・（比喻表現の認定にあたって）単語の由来はまれな例でのみ考虑される

図 2 MIPVUによる MIP の拡張（著者訳）

Contemporary English4を用いる。2つの辞書でも判断がつかない場合は, Oxford English Dictionary 5 を用いる。基本義の認定に，通時的な語源を重視しないことが明記されている。また， 比喻と判断されうるものを網羅的に抽出することを目指しているが, 概念メタファー (conceptual metaphor) は認定しない.

\section{2 中村の『比嗡表現の理論と分類』}

日本語比喻表現の実態調査に, 明治〜昭和期の文学作品 50 種から比喻情報の抽出を行った国 立国語研究所報告 57 『比喩表現の理論と分類』(中村 1977) があり, 我々の研究の比喻の定義は 中村 (1977) の研究に基づく，中村は, 日本語の比喻表現を, 受容過程における比喻性把握に着 目し，次の 3 類型に分類している：

- 第 1 類 指標比喻

受容主体が表現主体の比喻意識を感じ取る，換言すれば，受け手側での比喻の成立に直 接に形式的に慣用している，特定の言語形式をそなえており，それをく中略＞2 項間の 関係の特異性としてでなく，他から独立に抽出できる種類の比喻表現

- 第 2 類 結合比喩

何らかの言語単位の結びつきに，慣用からの顕著な逸脱または非論理性，少なくとも言 語上の論理的な飛躍が感じられる種類の比喻表現

- 第 3 類 文脈比喻

比喻の目印となる指標も, 要素間の結合上の異常性も特に認められないが, その表現形 式が表す言語的な意味と, それがその場であらわしていると思われる個別的な意味との 対応に慣用から著しいずれが意識される種類の比喻表現

第 1 類の指標比喻は，手掛かり句を持つ表現で技法としては直喻 (simile) に相当し，中村は

\footnotetext{
${ }^{4}$ https://www.ldoceonline.com/

5 https://www.oed.com/
} 
例文 (1) をあげている。ここでは，実際に行われた事柄の非現実性を表現するために，「宙を歩 いている」という表現により喻えている6とするが,「ような気がする」という形式によって, 比 喻であることが把握される例である.

（1）耕はひたいに汗をおぼえた。息が苦しくなった。宙を歩いているような気がする。

(「顔」丹羽文雄)

第 2 類の結合比喻は, 技法としての隠喻 (metaphor) に相当し, 中村は例文 $(2)$ をあげている. 例文中には複数の比喻表現がみられ, 仮想の抽象体である「えたいのしれない不吉な塊」が, 精 神活動の抽象体である「私の心」に対して，物理的な働きかけである「圧えつけ」を行ってい る，全体として文字どおりの解釈ができない見立てとする.

(2) えたいのしれない不吉な塊が私の心を始終圧えつけていた。

(「檸檬」梶井基次郎)

第 3 類の文脈比喻は，言語形式も構成要素間の結びつきの異常も持たない表現である，技法 としては諷喻 (allegory) にあたり，中村は例文 (3)をあげている。「打つべき釘を、打ち残した 気持ち」は，大工仕事をしたあとの気持ちを表すことも可能であり，「気組みを守った。」まで 読んだ全体としても文字どおりの解釈が可能である。しかし，前後の文脈から文字どおりの意 味ではなく何かの見立てであると感じる場合, 文脈中において文脈との無縁性のために比喻と なる例である。

（3）打つべき釘を、打ち残した気持ちがつづき、香奈江は、答えをせぬことで、わずかに相 手をはねかえす気組みを守った。

(「風ふたたび」永井龍男)

中村は「表現主体の比喻意識の反映とみられる何らかの言語形式をそなえており，それが受容 主体の比喻把握に一役買っている」場合を「A 型把握」とし，A型把握によって収集された指標 比喻にあたる用例を 1,617 種類の類型に整理し, 359 種類の比喻指標要素を体系化した. 本研究 においては,この中村の比喻指標要素の近傍に出現する比喻表現の収集を行う。指標比喻の全 数収集を目指すが, 結合比喻・文脈比喻が認められた場合にはデータベースに登録する。作業 に先立ち, 同書に含まれる比喻指標要素などの電子化を行った. 詳細については 3.2 節に示す.

\section{3 その他の日本語の比喻表現用例集および比喻表現コーパス}

本節では, 中村 (1977) 以外の日本語の比喻表現用例集および比喻表現コーパスの先行研究に ついて紹介する。最初に指標比喻（いわゆる直喻）関連の研究を紹介し，次に結合比喩（いわ

${ }^{6}$ 比喻を表す場合に「喻える」を用い, 例示を表す場合に「例える」を用いる，クラウドソーシング調査に扮ける実 験協力者への教示は,「たとえる」を用いた. 
ゆる隠喻）関連の研究を紹介する. 最後に書籍として出版されている比喻表現用例集を示す.

指標比喩関連：比喻表現の収集にあたり，比喻であることを明示する，比喻の指標（手掛か り句）となる表現を含む指標比喻（いわゆる直喻）は，指標を用いた比較的容易な収集が期待 される。過去の研究は比喻指標要素「ようだ」のみを対象とするものが多い。これらすべての 比喻指標要素を含む表現を収集すれば，多くの直喻用例が収集可能であるように思われる。し かし，指標は必ずしも比喻表現のみに含まれる語句ではない．指標を手掛かりにコーパスから 用例収集を試みる際にも，人手による判別作業が必須である。また，比喻指標の語句は，類語 や言い換えの可能な表現があり得るため多様であり，類似表現を網羅的に検索することも必要 になる。

古谷, 寺井 (2018) は, REX-J コーパス (Spanger, Yasuhara, Iida, and Tokunaga 2012) に含ま れる参照表現において比喻が用いられているかを検討した，須堯，寺井 (2019) は，青空文庫に 出現するデータから「ように」「ような」を比喻指標要素として 19,209 文の自動抽出を試みた. 抽出には係り受け解析器 (CaboCha) の出力に基づくパターンと分類語彙表番号に基づく喻辞の 制約を課している。但し, 我々の研究のように比喻と例示の区別はされていないと考えられる.

また，質問紙調査による指標比喻に対する小規模な評定調査が，心理学の分野で進められて いる，中本，楠見 (2004) は直喻形式の評定を行うために，「AはBのようだ」に修正可能な表 現を 500 以上収集した。収集元は，心理学研究の先行研究 (楠見 1995; Nakamoto 2003; Ortony, Vondruska, Foss, and Jones 1985) や比喻表現辞典 (榛谷 1988; 中村 1995) であった。 このうち 120 用例を取りあげ，理解可能性・構成語類似性・独創性・面白さについて 7 件法により 60-64 人規模で評定調査を行った。平，中本，楠見 (2007) は直喻文 30 文に対して，理解容易性・主 題と喻辞の類似性・表現の意外性・表現の親しみやすさ・面白さについて 5 件法で 70 人規模で 評定調査を行った。岡，大島，楠見 (2019) は，中本，楠見 (2004)の 120 用例について, 50 名 規模で解釈産出課題を行い，多義性の検討を行った。さらに 24 名規模で，9件法による表現の 選好性課題・喻辞の慣習性課題 (Bowdle and Gentner 2005; Utsumi 2007) を行った.

結合比喻関連：一方，比喻であることが比喻指標要素によって明示されない比喻表現の収集 は，指標比喻と比べて困難である。このうち, 結合比喻は, 基底となる語義の体系を決定した うえで，語義の連接・共起のちがいを手掛かりとした抽出が試みられている。なお，この語義 の連接・共起のちがいは，指標比喻においても有用な手掛かりであると考える。作業手順とし ては，基本的に 2.1 節に示した，MIP・MIPVU に基づく手法が利用される.

日本語でも，MIP を用いた比喻表現コーパスの構築を目指し(伊藤 2014), MIP, MIPVUに よる比喻判定も試みられている (宮澤, 吉田, 宮尾 2016). 宮澤他 (2016) は, MIP ・ MIPVU に基づき，『岩波国語辞典第五版夕グ付きコーパス 2004』を語義の判断基準とし，目的語・動詞 の結合についての比喻性判断（中村の結合比喻に相当）を 1,100 文に対して行った. 動詞の複 合語の語義判断については, 『複合動詞レキシコン』(神崎 2013)による. 
これに対し，本研究は MIP, MIPVUを BCCWJ のコアデータおよび『分類語彙表』(国立国 語研究所 2004)の語義に基づき整理を行う（3.1節）。分類語彙表の語義情報である分類番号が 付与されたデータ BCCWJ-WLSP (加藤, 浅原, 山崎 2019b) を基底となる語義の体系とし, 2.2 節に示す中村 (1977) に基づく比喻指標要素と語義の連接・共起に基づく比喻表現の収集作業を 行った。ささらに, 全文を対象として比喻指標要素を用いない, 語義の連接・共起のみに基づく, 結合比喻の収集作業についても着手している (Kato and Asahara 2019).

その他：紙の辞典形式の比喻表現用例集として, 榛谷 (1988), 中村 $(1995,2007)$, 野内 (1998, 2005), 佐藤, 佐々木, 松尾 (2006) などがある.

\section{3 指標比喻データベースの構築手法}

\subsection{MIP に基づく日本語指標比喻データベース整備作業の全体像}

本節では指標比喻データベース整備作業の全体像について解説する. 比喻用例収集手順とし て 2.1 節に示した MIP (Pragglejaz Group 2007)，MIPVU (Steen et al. 2010) を採用し，日本 語対応した．本研究の比喻表現の捉え方は 2.2 節に示した 中村 (1977) に基づく. 本研究の基 本的な対象は, 比喻指標要素の近傍に, 非慣用, 非論理的など, 基本義の用法から逸脱した異 例の結合を, 何らかの比喻的転換として確認できる用例である。しかし, 指標比喻の用例は概 ね結合比喻と重複するが, 言語形式が認められても結合の確認が困難な例や, 言語形式（指標 と認定する範囲）が不明瞭である例, 結合要素そのものよりも周辺語句の影響が強くみとめら れる例などもあるため, 関連語を漏れのないよう収集する必要がある. MIP を用いることで, 語単位に比喻性の判定が可能となり, 広く比喻表現に関係する要素の収集が可能となる。また, 比喻的な転換の見られる要素の結合に着目し，慣用からの逸脱を確認する点においても，基本 義との対照を行う手法が有用であると考えられる，但し，この比喻的な転換の認識は，主観的 なものであり，客観性を持たせることは本質的に困難である.

以下では, 図 3 に, 図 1 に示したオリジナルの MIP に対応する形式で, 日本語において言 語資源を援用しながら客観性を担保して比喻表現を抽出する指標比喻データベース構築手法を 示す。 日本語比喻表現抽出手順の概要について示す。まず最初にテキストを読んで語義の理解 を行う (1). 比喻用例収集にあたっては中村 (1977) の 359 種類の比喻指標要素とその類似用例 (『分類語彙表』(国立国語研究所 2004) により判定）を手掛かりとし，その近傍を調査する。本 研究の前提となる比喻指標要素の詳細を 3.2 節に示す. 比喻用例収集対象を BCCWJコアデー タ 6 レジスタ（Yahoo!知恵袋・白書・Yahoo!ブログ・書籍・雑誌・新聞） 1,290,060 語 57,256 文 とする．比喻用例収集対象の一部には『分類語彙表』(国立国語研究所 2004)の語義（分類番号) が付与されている。 また，同じサンプルに助動詞の用法が付与されている，本研究で語義の転 換の認識に用いる語義・用法アノテーションの詳細を 3.3 節に示す。次に単位を決める $(2)$. 本 
(1) 手掛かりとなる比喻指標要素の近傍にあるテキストを読んで文意の理解を行う（比喻指標要素の詳 細については 3.2 節を参照).

（2）分析単位を決める．文脈比喻以外の語義の分析単位として国語研短単位を基本とする.

(3) 各単位の語義の認定を行う. 語義の認定にあたっては『分類語彙表』の分類番号を基本とする. (i) 基本的にテキストを読んで作業を行うが, 3.3 節に示す語義アノテーション (加藤 他 $2019 \mathrm{~b}$ ) が 利用できる場合には語義アノテーションを援用する．語義の認定基準は (加藤 他 $2019 \mathrm{~b}$ ) を参照さ れたい.

(ii) 基本義の同定にあたっては

- 『日本国語大辞典』(concrete, precise, historical order)

- 分類語彙表における代表義 (山崎, 柏野 2017)

・語義アノテーション (加藤 他 2019b) における頻出義

を参考にする.

(iii) 結合の比喻性の認識にあたっては,

- 基本結合

要素の基本義・代表義を認定したうえで，字義どおりに解釈できる要素の結合を指す。『動 詞の意味・用法の記述的研究』(宮島 1972) に記述されている「意味的に動詞と結合する語 の制限」に相当する.

- 比喻的結合 (中村 1977)

要素の基本義・代表義を認定したうえで，字義通りに解釈できない要素の結合を指す。中 村 (1977) の B 型把握（言語単位の結びつきにおける慣用からの逸脱）に相当する.

などを参考にする.

(iv) 文脈比喻の検討を同時に行う.

（4）（i）上記 (1)(2)(3)(i)〜 (iv) の手続きに基づき，比喻的な語義の転換・逸脱が認められた場合に「比 喻」と認定する (3.4 節).

(ii)

a.「比喻」と認定した場合には, 喻辞・被喻辞を同定し, その近傍の比喻的結合を抽出する.

b. 喻辞・被喻辞間もしくは結合の概念的写像である概念マッピングの類型や比喻種別を付与す る.

c. 手掛かりとなった比喻指標要素についても記録する（3.5 節）.

(iii）また，非専門家の評定情報をクラウドソーシングにより収集する（3.6 節）.

図 3 MIP に基づく日本語比喻表現指標比喻データベース整備作業

作業では国語研短単位を基本とした，次に各単位の語義を推定する (3)(i). 基本的にはテキス トを読んで作業を行うが, 語義アノテーションが利用できる場合には語義アノテーションを援 用する．さらに各単位について他の文脈での基本義との対照を検討する (3)(ii). 基本義の同定 においては, 『日本国語大辞典』7 のほか, 代表義 (山崎, 柏野 2017)・語義アノテーションの頻出 語 (加藤 他 2019b) などを手掛かりとする。また要素の結合の比喻性の認識にあたっては基本結 合 (宮島 1972) ・ 比喻的結合 (中村 1977) を確認する (3)(iii). 上記 (1)(2)(3)(i)〜 (iv) の手続きに

\footnotetext{
${ }^{7}$ https://japanknowledge.com/lib/search/nikkoku/
} 
基づき, 比喻的な転換のみとめられる結合と判定し, 比喻性を認定し, 喻辞の出現箇所の同定 を行う (4)(i). なお, 提喻など比喻的結合のみとめられないものも, その喻辞の出現箇所同定お よび比喻表現該当部の同定を行う。比喻表現には，比喻指標要素・比喻表現該当部・喻辞・被 喻辞・結合・類型化・比喻種別（擬人・擬生や換喻・提喻・慣用など）を付与する (4)(ii). 詳細 については 3.5 節で述べる。最後に，比喻表現に対する非専門家の評定值をクラウドソーシン グにより収集する (4)(iii). 3.6 節に評定值の収集手法について示す.

なお, MIP は Metaphor（隠喻, 中村 (1977)の結合比喻・文脈比喻）を主対象とした手法で ある. MIPを拡張したMIPVUは, 比喻指標要素に該当する「MFlag」の付与も行っているが, 指標比喻を Metaphor と区別するものではない. 本作業は, 指標のあるいわゆる Simile（直喻, 中村 (1977) の指標比喻) を主対象とするが, 概ね同時に結合比喻が確認できる（比喻的な転換 に差がない）ことから，収集した表現が Metaphor と別種とは位置づけない。また，類似に基 づく典型的な転換ではない，いわゆる換喻（事物・事象の隣接性という類縁関係に基く「質的 転換」）や提喻（類と種という概念の「量的転換」）のような用例も, 要素の結合における比喻 的転換の把握によって取得される8。 このほか, 比喻指標要素を用いることで, MIPにおいて も作業効率のあがる可能性を期待した。いずれ比喻指標要素と共起しない第 2 類結合比喻・第 3 類文脈比喻も収集するが，本稿では網羅的な比喻データベース構築の出発点として，また指 標比喻用例の実態分析を進めるために，3.2 節に示す中村 (1977) の比喻指標要素を手掛かりと した作業を行う。さらに比喻指標要素については，分類語彙表番号に基づく同義性を用いた沉 化も試みる。

\section{2 中村 (1977) の比喻指標要素と比嗡指標要素に対する分類語彙表番号付与}

本研究では, 受容過程における比喻性把握に着目し, 比喻意識の指標となる言語形式を有す る比喻 (指標比喻) のデータベース構築を目標とする。「あたかも」「まるで」「よう」など，手 掛かり句である「比喻指標要素」が明示的に出現する，指標比喻の事例収集を行うことになる. 但し，指標は，比喻性を感じ取る (A 型把握) という点において有用な言語形式であるが，比 喻性の判断においては, 指標比喻も結合比喻や文脈比喻と同様の手順を必要とする。よって, 指標から当該表現に比喻性があるという可能性を感じるとしても, 比喻性の判断には根拠を要 する，そこで，本データベースにおいても，結合比喻・文脈比喻と同様，要素の結合や文脈 における慣用からのずれに着目した情報を含める。そのために『分類語彙表』(国立国語研究所 2004)の分類番号（分類語彙表番号）を語義の判断基準とした分析を進める.

我々は, 指標比喻データベースの整備のため, 中村 (1977) の指標比喻の 1,617 類型と 359 種類 の比喻指標要素を電子化し, 分類語彙表番号を新たに付与した。紙面から手入力し電子化ファ

8 「換喻」「提喻」の定義は (中村 1977 ) に基づく. 
イルを構築し, 形態素解析 MeCab と UniDic を用いて, 短単位形態論情報を付与した. その後, UniDic 語彙素-分類語彙表番号対応表 (WLSP2UniDic) $)^{9}$ (近藤, 田中 2020) を用い, 分類語彙表 番号を付与した。自動で付与できなかったものについては，人手で修正を施した。 中村 (1977) の類型は分類語彙表番号順に整理されており，本指標整備時から分類語彙表の体系を意識して いたことが推察される。

比喻指標要素は, その品詞から $\mathrm{D}$ 類 $($ 動詞 $) \cdot \mathrm{F}$ 類 (副詞 $) \cdot \mathrm{J}$ 類 (助詞 $) \cdot \mathrm{K}$ 類 (形容詞 ·形 容動詞 $) \cdot \mathrm{M}$ 類 $($ 名詞 $) \cdot \mathrm{R}$ 類（連体詞） $\mathrm{S}$ 類（接尾辞）に類型化されている。表 1 に例を示す. 「ようだ」以外にも多様な比喻指標要素が定義されていることがわかる，比喻指標要素は，類・ 種・号により階層化されている.

表 2 に比喻指標要素に対する分類語彙表番号割り当ての例として「よう（比喻指標要素の類 型：K-9-1・UniDic 語彙素：様)」を示す．多義である「よう」は，分類語彙表番号として 3.1300 の「様相」と 3.1130 の「類似」の 2 つを持つ.また, 同範囲には助動詞「ようだ」の用法として, 「類似」·「内容指示」·「例示」·「婉曲」の 4 つのいずれかが付与されている。このうち, 3.1130 「類似」の例のみが比喻表現に相当している。この分類語彙表番号を用いて，多義語に対する語 義の曖昧性解消を行いながらの比喻指標要素の抽出が可能になる。また分類語彙表番号が同じ 要素を類似比喻指標要素とし, 候補の抽出に用いる.

表 1 比喻指標要素の類型と例

\begin{tabular}{|c|c|}
\hline 比喻指標要素の類型 & 例 \\
\hline D～（動詞） & 感じる, たとえる, 気がする, 似る \\
\hline F （副詞） & まるで, いわば，仮に，ではあるまいし \\
\hline K （形容詞） & 近い, 同じ, 同類, その通り, よう \\
\hline $\mathrm{R}$ （連体詞） & へたな, 大した, いわゆる, 一種の \\
\hline M （名詞） & もの, ようす, 役目, たぐい, 錯覚 \\
\hline $\mathrm{J}$ (助詞） & ほど,でも, さえ, というものは \\
\hline S （接尾辞） & もの, 色, 様, ばり \\
\hline
\end{tabular}

表 2 比喻指標要素に対する分類語彙表番号割り当ての例：「よう」分類番号 3.1300 （様相）と 3.1130 (類似)

\begin{tabular}{cccc}
\hline 類 & 部門 & 中項目 & 分類項目 \\
\hline 相 $(3)$ & 抽象的関係 $(.1)$ & 様相 $(.13)$ & 様相・情勢 $(.1300)$ \\
相 (3) & 抽象的関係 $(.1)$ & 類 $(.11)$ & 異同 · 類似 $(.1130)$ \\
\hline
\end{tabular}

\footnotetext{
9 https://github.com/masayu-a/wlsp2unidic
} 


\section{3 『現代日本語書き言葉均衡コーパス』に対する分類語彙表番号アノテー ションおよび助動詞用法アノテーション}

比喻表現は意味的な転換を含む表現であるため, 語義アノテーションを含むデー夕を用いる ことにより，効率的に抽出できる。 また比喻指標要素も多義性があるため, 助動詞の用法も含 めた語義アノテーションを用いることにより，作業者の負担を減らすことができると期待され る. 本研究では語義アノテーションとして BCCWJ コアデータの一部 に対する分類語彙表番 号アノテーションデータ (加藤 他 $2019 b)$ を用いる.

同データは，前述の UniDic 語彙素-分類語彙表番号対応表 (WLSP2UniDic) により, BCCWJ の言語単位（短単位・長単位）に対応可能性のある分類語彙表番号を列挙したうえで，人手で 文脈上の正しい語義を選択したものである。列挙された分類語彙表番号の選択肢に該当する意 味分類がない場合には，新たに適切な番号を付与してある. BCCWJコアデータにはアノテー ションの優先順位 ${ }^{10}$ が規定されており，レジスタ毎に A, B , C , D, E までの 2-5の集合に分割さ れている。分類語彙表番号はサンプル PB (A), PB (B), PM (A), PM (B), PN (A), PN (B)（書 籍・雑誌・新聞） 347,094 語 15,969 文の短単位すべてに人手によって付与されている.

表 3 に分類語彙表番号アノテーション例を示す。この例では，比喻指標要素である「よう」 に,「関係-類-異同・類似」を示す「.1130」の分類語彙表番号下 4 ケ夕が付与されており, 続く 「闇を体験する」という結合から，比喻表現であるとされる。さらに喻辞「闇」の語義 1.5010 （体-自然-自然-光）が, 被喻辞「サブリミナル」の語義 1.3001 (体-活動-心-感覚) に転換されて

表 3 BCCWJ に対する分類語彙表番号アノテーション

\begin{tabular}{lll}
\hline 表層形 & 分類番号 & 分類 \\
\hline $\begin{array}{l}\text { サブリミナル } \\
\text { の }\end{array}$ & 1.3001 & 体-活動-心-感覚 \\
よう & & \\
に & 3.1130 & 相-関係-類-異同·類似 \\
闇 & & \\
を & 1.5010 & 体-自然-自然-光 \\
体験 & 1.3050 & 体-活動-心-学習・習慣・記憶 \\
し & 2.3430 & 用-活動-行為-行為・活動 \\
て & & \\
いる & 2.1200 & 用-関係-存在-存在 \\
わけ & 1.1113 & 体-関係-類-理由・目的・証拠 \\
た & & \\
\hline
\end{tabular}

(サンプル ID：PB12_0000，『闇を歩く』中野純（著)）

\footnotetext{
10 https://github.com/masayu-a/BCCWJ-ANNOTATION-ORDER
} 
いることもわかる.

上に述べた分類語彙表番号は自立語が主な対象であるが，付属語の情報として，同範囲に助 動詞の文法的な用法が別途付与されている (加藤, 浅原, 山崎 2019a). 以下の例文 (4)では, 2 つ出現する「よう」のうち，前者は比喻指標要素になる「類似」用法であり，後者は「内容指 示」用法である，助動詞の用法アノテーションにより，後者の比喩指標要素の語義の判定が不 要になる.

（4）転機はひとみさんが六年生のとき。研究のため家族四人そろって渡米した。不登校は相 変わらずだったが、本に興味を持ってくれた。日本から送った古典の現代語訳作品をは じめ、本棚に並ぶ本をむさぼり読んだ。一緒に行動しようと自分が好きな舞台に連れ出 すと、長時間のオペラを食い入るように見つめていた。帰国後、中学校の校長は「特別 扱いはできないが、卒業証書は出す」と言った。不登校に加え、何度となくリストカッ トも繰り返す。カウンセリングにも通った。本格的に小説を書くようになったのもこの ころだ。

（サンプル ID：PN4g_00003 ${ }^{11}$ ，西日本新聞，下線部は著者による）

本データは BCCWJ のコアデータの一部であるが, 語義の曖昧性が解消されており, 指標比 喻データベースの整備作業の補助に利用できる。コーパスに分類語彙表番号と助動詞の用法が 付与されているため, あらかじめ判明している指標となりえる要素（自立語もしくは助動詞） については，多義語が比喻指標要素に適合するか否かの絞り込みを行える。また，3.4節で述べ るように，分類語彙表の同じ分類番号を持つ語のグループを類義語としてみなし，中村 (1977) の比喻指標要素の類義語を新しい手掛かり語として展開する。中村 (1977) の比喻指標要素は 分類語彙表番号順に整理されていることから，分類語彙表番号が抽出の手掛かりになると考え る。さらに，自動処理により比喻を検出する場合にも，UniDic 語彙素-分類語彙表番号対応表 (WLSP2UniDic)により，特徵量として分類語彙表の情報を用いることを想定する.

\section{4 比喻表現出現箇所同定}

次に比喻表現出現箇所同定の詳細について示す.

中村 (1977) の比喻指標要素を BCCWJ コアデータ全体 1,290,060 語 57,256 文に対して語彙 素のパターンマッチにより枚挙した. 抽出された比喻指標要素の前後文脈 100 形態素を与え, 言語学の知識を持つ者 2 名により比喻表現であるか否かの判定を行った.

さらに, 分類語彙表番号で類義語句を展開したうえで, 比喻表現候補を枚挙した。中村 (1977) の比喻指標要素に付与された分類語彙表番号で, BCCWJ コアデータの分類語彙表番号付与済

11 BCCWJ におけるサンプルの識別子. 
表 4 比喻指標要素による候補数と抽出用例数

\begin{tabular}{lrrr}
\hline \hline 比喻指標要素 & 抽出用例数 & 候補数 & 抽出用例 $/$ 候補 \\
\hline \hline $\mathrm{D}$ (動詞) & 323 & 33,231 & $1.0 \%$ \\
\hline $\mathrm{F}$ (副詞 $)$ & 113 & 33,070 & $0.3 \%$ \\
\hline $\mathrm{K}$ (形容詞) & 444 & 1,707 & $26.0 \%$ \\
\hline $\mathrm{R} \quad$ (連体詞) & 0 & 1,840 & $0.0 \%$ \\
\hline $\mathrm{M} \quad$ (名詞 $)+\mathrm{J}$ (助詞 $)+\mathrm{S}$ (接尾辞) & 84 & 5,729 & $1.5 \%$ \\
\hline 分類語彙表番号 & 56 & 21,541 & $0.3 \%$ \\
\hline
\end{tabular}

み部分 347,094 語 15,969 文（書籍・雑誌・新聞）に対してパターンマッチを行い, 前後 100 形 態素を展開し，比喻表現であるか否かの判定を行った。例えば, D1類については,「2.3001（感 覚 $) 」\lceil 2.3061$ (思考 $) 」\lceil 2.3062$ (注意・認知 $) 」\lceil 2.1130$ (類似) 」「2.3066 (判断・推測)」「2.1310 (風・観・姿)」「2.3103 (表現)」などが対応する分類語彙表番号であった。この分類語彙表番号 により展開し，短単位では 3,060 例，長単位では 539 例が候補として得られた。この分類語彙 表番号に基づく用例では，短単位で $1.3 \%$ にあたる 41 例，長単位で $0.7 \%$ にあたる 4 例が比喻表 現を含んでいた。

表 4 に, $\mathrm{D}$ 類 $($ 動詞 $) \cdot \mathrm{F}$ 類 $($ 副詞 $) \cdot \mathrm{J}$ 類 $($ 助詞 $) \cdot \mathrm{K}$ 類 $($ 形容詞 - 形容動詞 $) \cdot \mathrm{M}$ 類 $($ 名詞 $) \cdot$ $\mathrm{R}$ 類 (連体詞) $\cdot \mathrm{S}$ 類（接尾辞）および分類語彙表番号により展開された比喻指標要素によって 展開された候補数と抽出用例数を示す，K（形容詞・形容動詞）は「よう」「みたい」などの率 が高い要素が多い一方， R (連体詞) は 1 件もなかった。分類語彙表番号により汎化したパター ンのうち, 実際に比喻表現の指標であったものは $0.3 \%$ であった.

基本的に 1 つ比喻表現該当部に 1 つの喻辞が出現するように抽出する ${ }^{12}$. 1 つの比喻用例が 複数の比喻指標要素を含む場合（複合用例）もあり，その場合は重複して確認するが, 1 つの比 喻表現該当部として抽出する。ささらに，目的の比喻指標要素ではない要素による比喻表現該当 部（指標外比喻用例）も抽出した。このため比喻指標要素と比喻表現が必ずしも 1 対 1 対応す るわけではない. 結果, 822 件の比喻表現該当部が抽出できた。 このうち, 複数（2つ以上）の 比喻指標要素を含む複合用例は 157 件で, 指標外比喻用例は 10 件であった。

\section{5 比喻関連情報アノテーション}

抽出された 822 件の比喻表現に対して, 言語学の知識を持つ者 2 名により関連情報のアノテー ションを行った，表 5 に比喻情報アノテーション例を示す。この事例を用いて比喻関連情報ア ノテーション作業の概要を説明する.

作業者は，3.4節の作業により此喻表現出現箇所同定を行う際に，比喻指標要素の前文脈 100

12 但し, 被喻辞・喻辞が明確でない提喩や文脈比喻が単体で出現する場合においてはこの限りではない. 
表 5 比喻関連情報アノテーション例

\begin{tabular}{|c|c|c|}
\hline 前文脈 & 比喻指標要素 & 後文脈 \\
\hline $\begin{array}{l}\text { 」とよばれ、うやまわれてきた。三原山の噴火 } \\
\text { が、観光客をよび、島を豊かにしてきたのだ。 } \\
\text { その三原山が、十五年前、五百年ぶりに大噴火を } \\
\text { おこした。十カ所以上の火口から、溶岩がふたた } \\
\text { したのだ。 流れ出た溶岩の跡が、幅百メート } \\
\text { ル、長さ三キロメートルもの大きさで、今も残っ } \\
\text { ている。その姿は、 }\end{array}$ & まるで & $\begin{array}{l}\text { 巨大な黒へビのようだ。ここを訪れた観光客は、 } \\
\text { 当時のすさまじさにふれて、息をのむ。ゴツゴツ } \\
\text { とした黒い地面が広がり、ところどころにまっ黒 } \\
\text { にこげた木の切れはしが落ちている。火口だっ } \\
\text { た場所は、すり鉢のように深くえぐれている。け } \\
\text { れど、今はそこに緑の木がのび、時の流れを感じ } \\
\text { させる。 大噴火のとき、島民一万人全員を島の } \\
\text { 外に }\end{array}$ \\
\hline
\end{tabular}

比喻表現該当部

流れ出た溶岩の跡が、幅百メートル、長さ三キロメートルもの大きさで、今も残っている。その姿は、まるで巨 大な黒へビのようだ。

\begin{tabular}{llll}
\hline \hline 結合 & 被喻辞 & 喻辞 & 備考 \\
\hline 跡が蛇 & 流れ出た溶岩の跡 $($ その姿) & 巨大な黒へビ & まるで・よう \\
\hline \hline 類型 $\mathrm{A}$ & 付属語 $\mathrm{A}$ & 類型 $\mathrm{B}$ & 付属語 $\mathrm{B}$ \\
\hline 跡 & 八 & ヘビ & ノヨウ \\
1.1720 & & 1.5503 & \\
\hline \hline 種別 & & 比喻指標要素分類 & \\
\hline 擬生 & & $\mathrm{F}-1-1 \cdot \mathrm{K}-9-1$ & \\
\hline
\end{tabular}

形態素と比喻指標と後文脈 100 形態素（表 5 上部）の比喻用例を見て，何らかの要素の結合に おいて慣用（基本義）からの逸脱を含むと判断した喻辞（喻える語）の位置を同定し，その文 脈を比喻表現該当部として抽出する。提喻などで，喻辞が明確化されない場合は，提喻の出現 位置を同定し，その文脈を比喻表現該当部として抽出する。この比喻表現該当部に対して，次 に示す結合・被喻辞 (喻えられる語) ・喻辞・類型・種別・比喻指標要素分類などの情報を付与 する。

結合：結合は，被喻辞相当句が文脈上語義的に逸脱しない文脈において，喻辞相当句が語義 的に逸脱して位置する場合，比喻的結合として逸脱が確認できる語句の連接を抽出する。用例 によっては, 複数の結合を含む. 要素の結合の欄には「跡が蛇」という結合に比喻的な語義の 転換があると判定した旨を記載する。但し，例示や指示に近い用法 (境界事例), 指標がなけれ ば成立しない表現などは，可能な形で記述し，種別欄にその旨を付記する。また，提喻のよう に本質的に比喻的結合がみとめられない事例13もある。基本結合か否かの判定には，分類語彙 表に基づく動詞の結合価の大規模な資料である 宮島 (1972) を参照する。また，中村 (1977)の 305 ページ以下に比喻的結合 5,537 例 ${ }^{14}$ が示されており，これらも参考にする.

被喻辞・喩辞：被喻辞は「喩えられる語」，喻辞は「喩える語」を意味する。表 5 では，被喻

\footnotetext{
13 例えば,「空気のような存在」「どこかこの世ではない場所」のような提喻の例などでは, 用例中に被喻辞・喻辞が 明示されないため, 比喻的結合も確認できない.

14 本作業に先立ち, 中村の比喻的結合についても MS Excel 形式に入力したうえで, 分類語彙表番号を付与した.
} 
辞である「流れ出た溶岩の跡 (その姿) 」15 と喻辞である「巨大な黒へビ」を抽出する．比喻表 現（概念マッピング）であることを読み取るにあたり，喻辞や被喻辞は結合から直接取得でき ない（「時代が瘦せる」など）例が多いが，喻えるものと喻えられるものの認識が必要である. 要素の結合に何らかの比喻的な語義の転換があることを明確化するとともに, 概念マッピング の類型化の補助として収集する，比喻用例中に明記がなければ前後文脈から取得するか文脈を 整理して記入する ${ }^{16}$ が，先に述べた提喻をはじめ，いずれも不明瞭で取得できない場合がある.

類型：類型は，比喻的結合に対して，字義どおりの解釈ができない（つまり, 基本結合から逸 脱している）ことを明らかにするための形式である．結合を要素に分解したもので，結合に含 まれる喻辞と連接する語との間には比喻となる語義的な転換があり，その語義的な転換が分類 語彙表上のどの語義とどの語義が基本結合から逸脱して連接しているかを示すものである．喻 辞の語義を被喻辞の語義に置き換えると基本結合になることを想定する，類型には，語義の転 換のある結合に相当する要素とその分類語彙表番号，付随する付属語の情報（結合の関係）を 記載する。なお，結合要素が固有名詞をはじめ複雑な構成を有した表現であるなどの場合には， 分類語彙表番号が付与可能なレベルに概念化する。この類型の分類語彙表番号の差異から，ど のような語義の間に転換が起きているのかが観察できる，さらに，電子化した中村の比喻的結 合 5,537 例と対照することも可能である.

種別：種別には，擬人化・擬物化・擬生化・具象化など, 比喻性の判断根拠となった要素の 結合分類，喻辞と被喻辞の関係にあたる概念マッピング情報を付与する.

a). 『擬人』化（物（抽象物・具体物）を人に喻える）

例）「溶岩が島民をあざ笑う（かのように）」「時代が瘦せている（みたい）」

b). 『擬物』化（人を物に喻える）

例）「私を貴方の道具として抒使いください」「平七郎が彫像のように立つ」

c). 『擬生』化（動植物に喻える, 活喻, 準擬人化)

例）「生き物としての音楽」

d). 上記外の『具象』化（抽象物を具体物に喻える）

例）「学術研究の基盤（として)」「心を洗われた（と感じる）」

e). 上記外の『抽象』化（具体物を抽象物に喻える）

例）「何かの啓示のように雲が浮かぶ」

f)．その他の『転換』(上記外の別種の物事に喻える)

例）「被害想定は防災カルテ（として)」「マエストロを歌舞伎役者にたとえた」

15 ここでは, テキスト中に捛いて同定可能な語句として抽出している. なお，MIP の手順により，複数の作業者が 各々比喻性を感じた短単位全てへのマークを別途行っている.

16 ゼロ代名詞や省略など，比喻表現該当部に被喻辞が文字列として出現しない場合は，「\#」を付記し，喻えられてい るものを記述する。 
上記 a)〜e）は，類似性に基づく転換の，人（生物）・物体・抽象体における大まかな概念マッ ピングであり，中村 (1977) の結合類型の 9 割以上が上記 $\mathrm{a})$ e) に分類される．しかし，他の事 物・事象に置き換える際には，それほど大きく移行しない場合も見られる。たとえば，液体を 気体に喻える (体の転換), 聴覚を視覚に喻える（感覚の転換），哺乳類を鳥類に喻える（界の転 換）などの転換が含まれる。本作業においては，このような小規模な転換の出現頻度の少ない ことが予想されたため，その他の「転換」としてまとめることにした．但し，後に付与する分類 語彙表番号の中分類などにより，詳細な分類が可能である。なお，MIPVUでは personalization （擬人化）を定義する ${ }^{17}$ が，日本語の比喻の議論で言及される，擬物化・具象化・抽象化といっ たものは導入されていない.

以上の一般的な類似性に基づく転換のほか，語感のずれなどで感じやすい類と種の関係（量 的転換）を判断根拠とした場合は『提喻』と分類し，付属物や中身を用いてあるもの全体を表 現しているなど，隣接性（質的転換）を判断の根拠とした場合には『換喻』と分類した18.文 脈比喻である（結合要素からのみでは判定できない）場合は『文脈』に分類し，慣用表現と判 断された場合などは『慣用』に分類した。指標要素が別用法である可能性も考えられた場合は, 「例示」「指示」「非断定」などの用法を『その他』として付記した.

これらの種別情報は，被喩辞-喩辞間・結合単位 ${ }^{19}$ に付与を行うため, 複数の結合を持つ $1 つ$ の比喻表現に対して複数の種別情報を付与する場合がある。例えば,「イカソーメンは、生のイ カを二枚あるいは三枚に分け、素麺のように細く切り ...」では，結合「イカが素麺」(『転換』) と結合「素曙のように細い」(『提喻』）の 2 つの結合に対して付与し用例全体には『転換-提喻』 とタグ付けする20. また，「肝臓はすっかりブルーになっていたのか」という表現においては， 「肝臓（の状態）」に対して『提喻』を付与するほか，結合「ブルーにな（る）」(『換喻』）と結 合「肝臓がブルーにな（る）」(『擬人』）の 2 つの結合に付与し，用例全体には『提喻-換喻-擬 人』を付与する。さらに 1 つの結合が複数の種別ラベルを持つ場合がある。例えば，「その事態 は会社がつぶれるようなもので」という表現中の結合「会社がつぶれる」に対しては，『具象。 換喻_慣用』の複数ラベルが付与される.

比喻指標要素分類・備考：最後に，出現した中村 (1977) の比喻指標要素の分類記号「F-1-1 (副詞：まるで）・K-9-1（形容詞：よう)」を付与する。比喻性に関わると考えられた指標要素 全てにタグ付けする。備考には関連する情報を付与する。喻辞と被喻辞を含め，比喻性に関わ ると考えられた語句を可能な限り収集した。

\footnotetext{
17 MIPVU の定義では擬人化に擬生化の一部が含まれている可能性がある.

18 『換喻』・『提喻』(『メトニミー』・『シネクドキ』) は研究者により，指すものが異なる傾向がある。本研究における 分類は中村 (1977) に基づく.

19 『提喻』などは単体の表現に,『文脈』はより広い範囲の表現に付与することもある.

20 比喻表現該当部全体に対して付与する場合には，結合（要素）間の種別の共起を“_”で，結合（要素）内の種別の 共起を“_”で表す.
} 


\section{6 クラウドソーシングによる評価}

これまでの作業は言語学の背景知識を持つ者により進めたが，専門的知識を持たない者が指 標比喻表現をどのように捉えるかは明らかでない，そこでクラウドソーシングにより，表現に 関する 3 つの観点（比喻性・新奇性・わかりやすさ）と，3つの観点との関連性を調査するため の 2 種（擬人化・具体化）を加えた 5 つの評価を行った。なお，表現に関する同様の質問紙調 査を中村 (1977) の例文（比喻表現のみ）や IPAL 辞書の動詞・形容詞の例文（比喻表現以外も 含む）にも行った。

・ 比喻性：何かを他の物事でたとえる (比喻) 表現を含むか21

提示する例文はすべて比喻表現を含んでいるが, 実験協力者が比喻であることを認識で きるかについて評価する

質問項目：「何かを他の物事でたとえる（此喻）表現をふくんでいますか.」

・ 新奇性：新しい表現を使っていると思うか

(比喻) 表現の新しさについて評価する.

質問項目：「新しい表現を使っていると思いますか.」

・わかりやすさ：わかりやすく表現されているか

(比喻) 表現を導入することによって，文意がわかりやすくなっているかわかりにくく なっているかを評価する。

質問項目：「わかりやすく表現されていると思いますか.」

以下は，比喻表現に多いとされる「擬人化」「具象化 (具体化)」が一般に読み取られるのかを 調査するために用いた観点である。これらの概念マッピングを読み取ることで，その他の観点 の判定に影響が現れるのかを調査するという補助的な目的で設定している.

・擬人化：人でないものを人に見たてているか

比喻であるとして，擬人化か否かが認識できるかを評価する。

質問項目：「人でないものを人に見たてていますか.」

- 具体化：具体的なものに見たてて説明しているか

比喻であるとして，具象化か否かが認識できるかを評価する，具象化が一般的な用語で ないために「具体的」という用語を用いた。

質問項目：「具体的なものに見立てて説明していますか.」

本調査は Yahoo!クラウドソーシングを用いて行った．対象は 20 歳以上の Yahoo!クラウド ソーシングのアカウント所持者であった. 調査協力者は, 上記 $5 つ$ 観点について, 「0：まっ たく違う」〜「5：そう思う」の 6 種類の評定值（6 件法）から 1 つ選択する. 前節で抽出され

21 我々は比喻性を二值的なもの（比喻であるか否かの二律背反なもの）ではなく, 程度性を持つものとして扱う. 
た 822 件の比喻表現該当部を 820 件に整理したうえで提示文とした ${ }^{22}$. 2019 年 2 月 15 日 8:00-2 月 16 日 00:10の間に異なり 1,657 人の評定值を収集した．5つの観点の組み合わせについて全 く同じパターンの回答を 5 回以上行った実験協力者を, データから除外し， 1,164 人分のデータ を分析対象とした．実験協力者は 6 用例を判定するごとに 10 円相当の $\mathrm{T}$ ポイントを得，最大 30 用例まで評価した。費用は 149,040 円であった。

結果， 1 つの例文に対する 22 人〜 77 人分の評定值（平均 33.0 人）を得た.

\section{4 比喻指標要素近傍における比嗡表現使用傾向の検証}

\section{1 アノテーションデータ}

以下ではアノテーションデータの分布について確認する.

表 6 にレジスタ毎の比喻表現該当部の分布を示す。レジスタの文数・形態素数が異なるため に 10,000 文あたりの相対度数，1,000,000 形態素あたりの相対度数で評価する。書籍 $(\mathrm{PB})$ が最 も多く, Yahoo!知恵袋 $(\mathrm{OC})$ や白書 $(\mathrm{OW})$ が少ない傾向にあった.

表 7 にレジスタ毎の種別の分布を示す。レジスタ毎に各種別の度数と相対度数（10,000 文あ

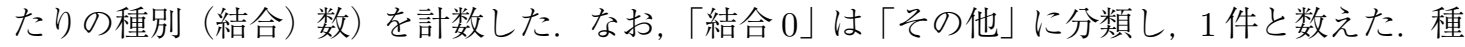
別は 1 つの事例に複数の結合を認定したうえで結合ごとに複数のラベルを付与する（マルチラ ベル）ため，レジスタ毎の総計は表 6 の比喻表現該当部数と異なる。種別を分類すると，「転換」 (小規模な転換) が多数を占める（10,000 文あたり 57.8 件）ことがわかる．文学作品の結合類型

表 6 比喻表現該当部および結合の分布

\begin{tabular}{|c|c|c|c|c|c|c|c|}
\hline & $\begin{array}{c}\mathrm{Y!} \text { 知恵袋 } \\
(\mathrm{OC})\end{array}$ & $\begin{array}{c}\text { 白書 } \\
(\mathrm{OW})\end{array}$ & $\begin{array}{c}\mathrm{Y} ! \text { ブログ } \\
(\mathrm{OY})\end{array}$ & $\begin{array}{l}\text { 書籍 } \\
(\mathrm{PB})\end{array}$ & $\begin{array}{l}\text { 雑誌 } \\
(\mathrm{PM}) \\
\end{array}$ & $\begin{array}{l}\text { 新聞 } \\
(\mathrm{PN}) \\
\end{array}$ & 全体 \\
\hline 比喻表現該当部数 & 25 & 48 & 63 & 299 & 198 & 189 & 822 \\
\hline （10,000 文あたり） & 40.9 & 82.4 & 89.2 & 308.9 & 157.9 & 117.8 & 143.6 \\
\hline$(1,000,000$ 形態素あたり $)$ & 226.7 & 210.4 & 537.4 & 1275.6 & 826.9 & 524.2 & 637.2 \\
\hline 結合 0 の比喻表現該当部数 & 0 & 0 & 1 & 2 & 1 & 0 & 4 \\
\hline 結合 1 の比喻表現該当部数 & 24 & 43 & 53 & 238 & 165 & 152 & 675 \\
\hline 結合 2 の比喻表現該当部数 & 1 & 4 & 8 & 52 & 31 & 31 & 127 \\
\hline 結合 3 の比喻表現該当部数 & 0 & 1 & 1 & 7 & 1 & 6 & 16 \\
\hline 形態素数 & 110,280 & 228,172 & 117,242 & 234,400 & 239,440 & 360,526 & $1,290,060$ \\
\hline 文数 & 6,110 & 5,825 & 7,059 & 9,678 & 12,542 & 16,042 & 57,256 \\
\hline
\end{tabular}

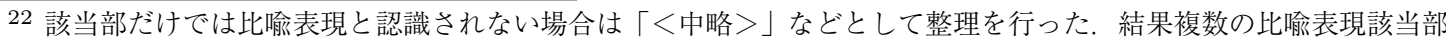
が 1 つに集約された場合があった。複数の比喻指標要素を持つ比喻表現該当部は複数回提示したが, 同一の比喻表 現該当部が同じ調査協力者に割り当てられないように配慮した。
} 
表 7 結合に割り当てられる種別の分布

\begin{tabular}{|c|c|c|c|c|c|c|c|c|c|c|c|}
\hline & 擬人 & 擬生 & 擬物 & 具象 & 抽象 & 転換 & 換喻 & 提喻 & 文脈 & 慣用 & その他 \\
\hline Y!知恵袋 (OC) & 0 & 2 & 0 & 2 & 0 & 6 & 1 & 1 & 2 & 11 & 3 \\
\hline （相対） & 0.0 & 3.3 & 0.0 & 3.3 & 0.0 & 9.8 & 1.6 & 1.6 & 3.3 & 18.0 & 4.9 \\
\hline 白書 (OW) & 1 & 0 & 1 & 24 & 0 & 5 & 1 & 1 & 0 & 23 & 0 \\
\hline （相対） & 1.7 & 0.0 & 1.7 & 41.2 & 0.0 & 8.6 & 1.7 & 1.7 & 0.0 & 39.5 & 0.0 \\
\hline Y!ブログ (OY) & 1 & 4 & 4 & 16 & 1 & 22 & 5 & 13 & 1 & 11 & 1 \\
\hline （相対） & 1.4 & 5.7 & 5.7 & 22.7 & 1.4 & 31.2 & 7.1 & 18.4 & 1.4 & 15.6 & 1.4 \\
\hline 書籍 (PB) & $\underline{31}$ & 20 & 20 & 66 & 0 & 147 & 16 & 45 & 2 & 32 & 19 \\
\hline （相対） & $\underline{32.0}$ & 20.7 & 20.7 & 68.2 & 0.0 & 151.9 & 16.5 & 46.5 & 2.1 & 33.1 & 19.6 \\
\hline 杂雑誌 (PM) & 9 & 13 & 8 & 26 & 2 & 85 & 6 & 35 & 2 & 37 & 25 \\
\hline （相対） & 7.2 & 10.4 & 6.4 & 20.7 & 1.6 & 67.8 & 4.8 & 27.9 & 1.6 & 29.5 & 19.9 \\
\hline 新聞 (PN) & 10 & 7 & 10 & 70 & U & 66 & 11 & 21 & 2 & 45 & 20 \\
\hline （相対） & 6.2 & 4.4 & 6.2 & 43.6 & 0.0 & 41.1 & 6.9 & 13.1 & 1.2 & 28.1 & 12.5 \\
\hline 総計 & 52 & 46 & 43 & 204 & 3 & 331 & 40 & 116 & 9 & 159 & 68 \\
\hline （相対） & 9.1 & 8.0 & 7.5 & 35.6 & 0.5 & 57.8 & 7.0 & 20.3 & 1.6 & 27.8 & 11.9 \\
\hline
\end{tabular}

注：(相対) 行は, 10,000 文あたりの種別（結合）数.

(中村 1977) では 1 割未満の種別であったことから, 隠喻として一般的ではない転換であるとも 考えられる，大きな転換であれば，カテゴリーの違いによって比喻性のあることが読み取りや すいが，小規模な転換であるがゆえに，指標を用いて比喻であるという把握を促す傾向が考え られる。比喻表現の使用実態における指標の必要性が考えられる。本データベースで収集した 用例の分析によって，指標を用いる必要のある表現の整理や，例示や内容指示など比喻との区 別が問題視される表現の傾向も明らかになると期待される.

擬人化は文学作品を含む書籍 $(\mathrm{PB})$ に多く（表 7 下線部）, 中村 (1977) 文学作品の結合類型 の分布（擬人化が全類型の $41.8 \%$ ）の結果と整合する.今後，書籍サンプルに付与されている NDC （日本十進分類法）の情報と対照することで，書籍のジャンル毎の検討を行いたい.

また, 抽象の用例が 3 件確認された. MIP, MIPVUのアノテーションの定義においては, 具 象化・具体化の方向で語義の転換があることを前提に比喻表現の認定がなされていたが，本デー タベースでは抽象化の方向でも語義の転換のあることが認められた。 今後, 他言語においても 抽象化の用例があるかを検討する必要があろう。

表 8 に比喻指標要素の頻度上位 10 件とその種別の分布を示す。よく直喻指標で用いられると 考えられているK-9-1「よう」は，357 例 23 （今回抽出した指標比喻用例の $43 \%$ ）に出現した. D-1-16「する」は「にする」「とする」が含まれ，特に慣用表現が多い傾向にある，K-9-3「みた い」と F-1-1「まるで」は小規模な転換（『転換』）が多い一方, D-1-1「感じる」は『具象』が多

23 種別は 1 事例に複数付与されるために行の合計より少ない数になる. 
表 8 比喻指標要素（頻度上位 10 位まで）と種別の分布

\begin{tabular}{ll|r|rrrrrr|rrrrr}
\hline 指標記号 & 指標要素 & 度数 & 擬人 & 擬生 & 擬物 & 具象 & 抽象 & 転換 & 換喻 & 提喻 & 文脈 & 慣用 & その他 \\
\hline K-9-1 & よう & 357 & 36 & 27 & 19 & 61 & 3 & 183 & 12 & 53 & 1 & 14 & 46 \\
D-1-16 & する & 223 & 7 & 3 & 10 & 79 & 0 & 17 & 11 & 9 & 1 & 124 & 2 \\
K-9-3 & みたい & 61 & 1 & 5 & 3 & 3 & 0 & 40 & 2 & 15 & 1 & 0 & 4 \\
F-1-1 & まるで & 47 & 3 & 5 & 2 & 3 & 1 & 29 & 1 & 4 & 1 & 0 & 4 \\
K-11-1 & である & 38 & 3 & 4 & 4 & 2 & 0 & 21 & 0 & 6 & 0 & 2 & 0 \\
M-1-2 & もの & 35 & 3 & 2 & 1 & 7 & 0 & 16 & 0 & 8 & 0 & 0 & 7 \\
D-1-1 & 感じる & 20 & 0 & 2 & 0 & 10 & 0 & 4 & 3 & 1 & 2 & 3 & 0 \\
D-1-2 & 思う & 18 & 1 & 0 & 0 & 4 & 0 & 8 & 1 & 2 & 1 & 4 & 2 \\
S-1-5 & ․ 状 & 18 & 0 & 0 & 0 & 1 & 0 & 14 & 0 & 2 & 0 & 0 & 1 \\
D-1-12 & たとえる & 14 & 1 & 0 & 2 & 2 & 0 & 7 & 1 & 1 & 0 & 0 & 1 \\
\hline
\end{tabular}

表 9 種別ラベルの共起

\begin{tabular}{|c|c|c|c|c|c|c|c|c|c|c|c|}
\hline & 擬生 & 擬物 & 具象 & 抽象 & 転換 & 換喻 & 提喻 & 文脈 & 慣用 & その他 & <単独 $>$ \\
\hline 擬人 & 5 & 1 & 9 & 0 & 13 & 0 & 4 & 0 & 0 & 0 & 25 \\
\hline 擬生 & & 1 & 8 & 0 & 9 & 0 & 5 & 0 & 3 & 1 & 17 \\
\hline 擬物 & & & 4 & 0 & 5 & 0 & 2 & 0 & 1 & 0 & 25 \\
\hline 具象 & & & & 0 & 23 & 5 & 14 & 1 & 24 & 8 & 90 \\
\hline 抽象 & & & & & 0 & 0 & 1 & 0 & 0 & 0 & 2 \\
\hline 転換 & & & & & & 8 & 20 & 1 & 4 & 0 & 241 \\
\hline 換喻 & & & & & & & 7 & 0 & 3 & 1 & 18 \\
\hline 提喻 & & & & & & & & 1 & 3 & 3 & 59 \\
\hline 文脈 & & & & & & & & & 0 & 0 & 6 \\
\hline 慣用 & & & & & & & & & & 0 & 119 \\
\hline その他 & & & & & & & & & & & 56 \\
\hline
\end{tabular}

かった．小規模な転換においては，「まるで〜のような」などの指標を組合せた類型が用いられ やすく, 言語形式によって比喻性の把握を促す傾向が強いといえる。「感じる」は身体性に関わ る比喻表現に用いられ(菊地, 加藤, 浅原 2018), 被喻辞が身体で感じることの可能な具体物に されることになる。

表 9 に種別ラベルの共起について示す。具象と転換（用例 (5)）, 具象と慣用（用例 $(6)(7) ）$, 転換と提喻 $(8)(9)$ が共起する傾向が見られた，具象化は一般に慣用化している例が多い. 用例 (5) は「作品が文化に筋を通す」(具象) と「作品のさわやかな筋」(転換_具象) の 2 つの結合 がある ${ }^{24}$. 用例 $(6)$ は「胸が空く」(具象) と「胸のすくような成功」(慣用) の 2 つ結合があ る.用例 (7) は「チャンスを手にする」（具象_慣用）の 1 つの結合がある. 用例 (8) は「得点で 王となる」(転換) と「日本語キング（日本語クイーン）」(提喻）の結合がある。用例 (9) は「相

24 用例単位のラベルとして結合（要素）間の種別の共起を“_”で, 結合（要素）内の種別の共起を“_”で表す（再掲）. 
撲取りみたいな体格」(提喻_転換）の 1 つの結合がある。なお， 3 つ以上ラベルが共起する場合 （用例 (10)：「政権が崩壊」（具象_換喻）・「崩壊が目の当たり」（具象）・「崩壊を目の当たりにす る」(慣用)）もある。

(5) 佐藤さんが指摘する「意地」は、大衆文化の中に、1本のさわやかな筋を通しているよ うに思える。

$$
\text { (「具象-具象_転換」サンプル ID：PN4a_00010） }
$$

（6）胸のすくような成功の軌跡を一挙公開

$$
\text { （「具象-慣用」サンプル ID：PM31_00275） }
$$

(7) タイ・バンコクではチャンスも手にした。

（「具象_慣用」サンプル ID：PN4g_00002）

（8）次回の試験は十一月です。最高得点者は日本語キング、日本語クイーンとして表彰され ます。

(「転換-提喻」サンプル ID：PN3b_00009）

（9）兄は独り者で、相撲取りみたいな体格だという話だった。（「転換_提喻」サンプル ID： PM31_00020)

(10)「私たちはイラクの中央政権の崩壊を目の当たりにしている」

(「具象_換喻-具象-慣用」サンプル ID：PN3a_00002)

\section{2 クラウドソーシングによる評定データ}

\subsection{1 クラウドソーシングによる評定值の基礎統計と上位事例・下位事例}

表 10 にクラウドソーシングによる評定のレジスタに基づく提示用例ごとの平均評定值の平 均 (用例単位マクロ平均) を示す。比喻性は, 書籍 $(\mathrm{PB}) \cdot Y$ ahoo!ブログ $(\mathrm{OY}) \cdot$ 杂隹誌 $(\mathrm{PM})$ が高 く, 白書 $(\mathrm{OW})$ が低い傾向が見られた。新奇性は, Yahoo!ブログ $(\mathrm{OY})$ ・書籍 $(\mathrm{PB})$ が高く, 白 書 $(\mathrm{OW})$ が低い傾向が見られた。わかりやすさは，Yahoo!知恵袋 $(\mathrm{OC})$ が高く，白書 $(\mathrm{OW})$ が

表 10 クラウドソーシングによる評定の分布（レジスタに基づく用例単位マクロ平均）

\begin{tabular}{l|rrrrrr|l}
\hline & $\begin{array}{r}\mathrm{OC} \\
\text { 知恵袋 }\end{array}$ & $\begin{array}{c}\mathrm{OW} \\
\text { 白書 }\end{array}$ & $\begin{array}{c}\text { ブログ } \\
\text { 総計 }\end{array}$ & $\begin{array}{c}\text { PB } \\
\text { 書籍 }\end{array}$ & $\begin{array}{c}\text { 雑誌 } \\
\text { 新聞 }\end{array}$ & \\
\hline 比喻性 & 2.30 & 1.66 & 2.80 & 2.93 & 2.76 & 2.50 & 2.69 \\
新奇性 & 1.70 & 1.49 & 2.08 & 2.06 & 2.01 & 1.85 & 1.96 \\
わかりやすさ & 3.19 & 2.87 & 2.96 & 3.06 & 3.03 & 3.12 & 3.05 \\
擬人化 & 1.43 & 1.29 & 1.54 & 1.56 & 1.45 & 1.48 & 1.50 \\
具体化 & 2.61 & 2.41 & 2.77 & 2.93 & 2.88 & 2.79 & 2.83 \\
\hline
\end{tabular}


低い傾向が見られた。擬人化は，書籍 $(\mathrm{PB}) \cdot Y$ ahoo!ブログ $(\mathrm{OY})$ が高く，白書 $(\mathrm{OW})$ が低い傾 向が見られた。具体化は, 書籍 $(\mathrm{PB}) \cdot$ 雑誌 $(\mathrm{PM})$ が高く, 白書 $(\mathrm{OW})$ が低い傾向が見られた. これらの傾向に対しては，実験協力者のバイアスを考慮したうえで統計的に分析する必要があ る. 4.2 .2 節で詳細に検討する.

表 11 にクラウドソーシングによる評定の種別に基づく提示用例単位マクロ平均を示す．比喻 性は，擬生が最も高く，慣用が最も低い傾向が見られた。新奇性は，抽象が最も高く，慣用が 最も低い傾向が見られた，わかりやすさは，転換が最も高く，抽象が最も低い傾向が見られた. 擬人化は，擬人・擬生が高く，慣用が低い傾向が見られた。具体化は，擬生が高く，慣用が低 い傾向が見られた。 また，具象が低く，抽象が高いという傾向も見られた。 これらの傾向に対 して，実験協力者のバイアスを考慮したうえで統計的に分析する必要がある。 4.2 .2 節で詳細に 検討する.

以下では，クラウドソーシングによる評定の上位事例・下位事例を検討する.

表 12 に比喻性の評定が上位の事例を示す。下線部は比喻指標要素を表す，比喻指標要素の範 囲が重なる場合は最大の範囲のみ示す。なお，クラウドソーシングの呈示画面には，比喻指標 要素が比喻性判断を促進しないように比喻指標要素を呈示しない.「顔／りんご」「海に浮かぶ 様／一本の棒」「本／宝石箱」といった結合は論理的に成立しないため, 非比喻の解釈が発生し にくいと考えられる。また，「赤さ」「線状」「高い価值」のような，喻辞の有する属性を根拠と する見立てであることが, 比喻性の判断に影響した可能性がある.

表 11 クラウドソーシングによる評定の分布（種別に基づく提示用例単位マクロ平均）

\begin{tabular}{l|rrrrrr|rrrrr}
\hline & 擬人 & 擬生 & 擬物 & 具象 & 抽象 & 転換 & 換喻 & 提喻 & 文脈 & 慣用 & その他 \\
\hline 比喻性 & 3.19 & 3.49 & 3.23 & 2.37 & 3.20 & 3.11 & 2.27 & 2.99 & 2.41 & 1.69 & 2.74 \\
新奇性 & 2.34 & 2.31 & 2.23 & 1.92 & 2.43 & 2.06 & 1.91 & 2.05 & 2.01 & 1.52 & 1.94 \\
わかりやすさ & 3.04 & 3.07 & 3.10 & 2.97 & 2.62 & 3.14 & 2.91 & 3.04 & 2.77 & 3.05 & 3.05 \\
擬人化 & 2.24 & 2.22 & 1.94 & 1.38 & 1.47 & 1.50 & 1.45 & 1.46 & 1.66 & 1.23 & 1.44 \\
具体化 & 3.00 & 3.17 & 3.06 & 2.53 & 3.05 & 3.10 & 2.51 & 2.98 & 2.55 & 2.25 & 3.00 \\
\hline
\end{tabular}

表 12 比喻性の評定（上位事例）

\begin{tabular}{|c|c|c|}
\hline サンプル ID & 比喻事例 & 比喻性 \\
\hline PB29_00013 & $\begin{array}{l}\text { 顔は、りんごのように赤く、目は、大きく、まんまるで、頭でっかちな子ども } \\
\text { です。 }\end{array}$ & 4.53 \\
\hline PB39_00023 & 泳ぎつかれたら一本の棒みたいに海水に浮かび、 & 4.47 \\
\hline PN2a_00017 & $\begin{array}{l}\text { 私はすぐ先の納屋に向かって䠃跚と足を運んだ。人が見たら糸操りの人形の } \\
\text { ような歩きかただったろう。 }\end{array}$ & 4.43 \\
\hline PB40 & してみるとこの本は、間違いなく私の「宝石箱」なのである。 & 4.43 \\
\hline PM11_00260 & 化粧が天才的にへタでピカソみたいなメークになってる女や、 & 4.41 \\
\hline
\end{tabular}


表 13 に比喻性の評定が下位の事例を示す。「口にする」「耳にする」「柱とする」「基礎にする」 が比喻性評定の下位に来た，前二者は，発話や聴取をその行為が行われる器官を用いて表現す る, いわゆる換喻である。一般に，換喻は「赤ずきん」「鍋を食べる」などの典型表現をはじめ， 意識的に用いられる例が少ないと考えられる。また，「柱とする」「基礎にする」は (Lakoff and Johnson 1980) でいうところの 'THEORIES ARE BUILDINGS' の概念メタファーに基づく比喻 表現である。人間の認知に根ざした比喻である場合，表現に対する異質性の印象が薄い可能性 がある。なお，PB35_00013の例において，比喻指標要素「となり」と「という」は，比喻表現 を構成する指標ではない。このような比喻指標要素は比喻性判断に影響を与えることが考えら れるため, クラウドソーシングの際には呈示していない.

表 14 に新奇性の評定が上位の事例を示す。「home／犠牲」「時代／瘦せる」「リアリティーの 無さ／スクリーンの向こう側」「闇／サブリミナル」「人生／ステップを刻みながら斜面を登る」 といった取り合わせの異常性が目立つ。また，瞬きによる一瞬の闇を「サブリミナル」として 捉え，死に至るまでの人生の歩みを「ステップを刻む」ものとして捉えるといった，通常なら

表 13 比喻性の評定（下位事例）

\begin{tabular}{|c|c|c|}
\hline サンプル ID & 比喻事例 & 比喻性 \\
\hline PB29_00003 & $\begin{array}{l}\text { 三宝が佐倉の名を口にした時こそそのチャンスだったのだが、なぜか言いそ } \\
\text { びれたのである。 }\end{array}$ & 0.50 \\
\hline PB29_00026 & アルコールをほとんどロにしなくなってずいぶんになる。 & 0.52 \\
\hline PB35_00013 & $\begin{array}{l}\text { ここまでが標準仕様で、あをはオプションとなります」という言葉をよく耳 } \\
\text { にしませんか？ }\end{array}$ & 0.55 \\
\hline OW6X_00073 & $\begin{array}{l}\text { タイ及びその周辺国への薬物分析技術の移転等を柱とする「薬物対策地域協 } \\
\text { カプロジェクト」に、 }\end{array}$ & 0.56 \\
\hline PN4d_00004 & 「具体的な議論の基礎にするために提案した」 & 0.65 \\
\hline
\end{tabular}

表 14 新奇性の評定（上位事例）

\begin{tabular}{|c|c|c|}
\hline サンプル ID & 比喻事例 & 新奇性 \\
\hline PB25_00063 & $\begin{array}{l}\text { 近年この国では肝心の hom e がなおざりにされて、容器にすぎない hou s e } \\
\text { を追い求める傾向が強い。主客転倒してhou s e を獲得するために ho m e が } \\
\text { 犠牲にされることたたって珍しくないのだ。 }\end{array}$ & 3.61 \\
\hline $\mathrm{PM}$ & なんか時代が瘦せてるって感じがするよね。 & 3.45 \\
\hline PN1c & $\begin{array}{l}\text { クローン人間という言葉は未だにリアリティーを獲得できずにいる。まるでスク } \\
\text { リーンの向こうのヴァーチャルな世界のことのように。 }\end{array}$ & 3.43 \\
\hline $\mathrm{PB} 12$ & $\begin{array}{l}\text { そう考えると、私たちは瞬きするたびに、ほんの一瞬ずつ、サブリミナルのよう } \\
\text { に闇を体験しているわけだ }\end{array}$ & 3.33 \\
\hline $\mathrm{PB} 25$ & $\begin{array}{l}\text { 人は最終的な h o m e （墓）にたどり着くまで、まるでステップを刻みながら（中 } \\
\text { 略）斜面を登るように営々と自分の居場所を探しつづけるしかないのだ }\end{array}$ & 3.30 \\
\hline
\end{tabular}


ば予測できないそれぞれの物事の側面を表現している。これが新奇性の一つの根拠になると推 測される。

表 15 に新奇性の評定が下位の事例を示す。「手にする」「後にする」「教訓とする」「目の当た りにする」といった「Xに（と）する」形式と「動きを止められたように」が評定の下位となっ ている。「Xにする」形式は換喻的に意味を形成するものであり，積極的に表現対象となる事物 をカテゴリーの異なる事物に見立てるものではない.「Xに（と）する」形式は比喻性の評定で も下位であったが, 新奇性も薄い.「動きを止められたように」は助動詞「よう」の様態用法と 区別しがたい境界的な例であり，比喻の新奇性という面では低いと判断されると予測される.

表 16 にわかりやすさの評定が上位の事例を示す。大人とて求められる性格・性質を欠いた 人間を「子供」と表現することは慣用的であるが,〈幼稚〉という明確な属性を付加することが できる，このように明確に属性が用いられる場合，理解されやすいと推測される，また，「噴火 ／噴水」や「大きな鉄船／巨大な壁」の取り合わせは被喻辞の様態を「噴水」や「巨大な壁」と いった視覚的なイメージを有する喻辞によって説明している。このように明確な視覚的イメー ジを用いた場合も理解しやすい比喻として判断されると推測される。「いつも黒い服を着ている 女性」を「葬式帰りのように見え」ると表現することは，「黒い服」が葬儀に着ていくことから， 連想が容易であることによりわかりやすくなるのだと推測される.

表 17 にわかりやすさの評定が下位の事例を示す。「強たる物欲しみして身を亡すに譬給える にや」は比喻関係の難しさよりも古語であるという文体による解読の難しさが存在する。また,

表 15 新奇性の評定（下位事例）

\begin{tabular}{l|l|r}
\hline サンプル ID & \multicolumn{1}{|c|}{ 比喻事例 } & 新奇性 \\
\hline PN5a_00005 & 1 回の公演で手にするお金は、交通費約 2千円。 & 0.64 \\
PN3b_00014 & 衆院が解散し、国会を後にする小池百合子 & 0.67 \\
OW6X_00040 & すべての都道府県で、阪神・淡路大震災を教訓とした見直しを行っているが、 & 0.67 \\
PB39_00013 & 兵はもとより庶民たちも動きを止められたように固まっていた。 & 0.70 \\
PN23_00006 & 事件を目の当たりにした子どもたちは、今なお深い心の傷に苦しんでいる。 & 0.76 \\
\hline
\end{tabular}

表 16 わかりやすさの評定（上位事例）

\begin{tabular}{l|l|r}
\hline サンプル ID & \multicolumn{1}{|c}{ 比喻事例 } & わかりやすさ \\
\hline PB39_00023 & あの人子供みたいだよね。 & 4.31 \\
PB1n_00024 & 溶岩は、粘りが少ないため、噴火すると噴水のようにふきあがる。 & 4.28 \\
OC09_00369 & 同じ部署にいつも黒い服を着ている女性がいて、全身黒で日傘やバッ & 4.26 \\
& グも黒なので、葬式帰りのように見えます。 & 4.25 \\
OW6X_00073 & 武器庫として使われたアパート & 4.20 \\
PB39_00009 & 大きな鉄船は巨大な壁のように目の前をふさいでいる。 & \\
\hline
\end{tabular}


「くず $\mathrm{C}\rfloor^{25}$ 「ヒョーヒボハン (表皮母斑)」のように被喻辞が馴染みの薄いものであり，何が 喻えられているのか分からない場合もわかりやすさが低くなると推測される。これらのわかり にくさは比喻の問題ではなく文体・指示物の問題である。「(処女の失い方が）天使のような捨 て方」であるという比喻は被喻辞である「処女の失い方」が明記されていないので，「天使」と 「捨て方」の結合から理解することになる，処女についての文脈が無い場合，両者の結びつきは 意外性があり，理解が難しくなる。「音楽としての意味思想の世界」は「音楽」に「意味思想の 世界」が存在すると捉えている。ただ，喻辞・被喻辞の両者ともに抽象的であり，具体性が伴 わないためにわかりやすさは低くなると推測される。

表 18 に擬人化の評定が上位の事例を示す。いずれの比喻表現も「月／王さま」「鳥／恋人」 「水 /友だち」「船 /片眼・横たえる」「道路・公園／養子」「ボランティア／里親」と喻辞が人 物・身体部位・動作であり，語彙的に人間であることが保証されている，人に喻えていること が語彙的に明確であることが擬人的であるという判断につながるのだと推測される.

表 19 に擬人化の評定が下位の事例を示す．擬人化的な比喻関係を持たない例が評定の下位と なっている。また，「火口／すり鉢」のように場所の特徴を具体的な物によって喻えている例は

表 17 わかりやすさの評定（下位事例）

\begin{tabular}{|c|c|c|}
\hline サンプル ID & 比喻事例 & わかりやすさ \\
\hline OY14_02403 & 「此御歌は人の強たる物ほしみして身を亡すに譬給へるにや」 & 1.02 \\
\hline PB32_00008 & $\begin{array}{l}\text { また反対に、よし天使のような捨てかたであっても、それが甲でもよしてでもよ } \\
\text { し、あるいは丙でもよかったというような場合を想像し得られませんか。 }\end{array}$ & 1.05 \\
\hline OY01_00848 & $\begin{array}{l}\text { そんな気がして、くずCをちょい宝くじ的に拾って期先でよを見るつもりなん } \\
\text { ですが? }\end{array}$ & 1.16 \\
\hline PB54_00015 & オビジョーニコマカナカッショクノイボガデキルヒョーヒボハン & 1.27 \\
\hline OY14_20592 & $\begin{array}{l}\text { 音楽が、言葉の介在しない音楽としての意味思想の世界を形成しつつ、確固たる } \\
\text { 意志のもとに紡ぎ合わさる。 }\end{array}$ & 1.29 \\
\hline
\end{tabular}

表 18 擬人化の評定（上位事例）

\begin{tabular}{l|l|r}
\hline サンプル ID & \multicolumn{1}{|c|}{ 比喻事例 } & 擬人化 \\
\hline PN2g_00004 & 月は大きくて王さまのようです。 & 4.21 \\
PN1d_00001 & 最初は離れてとまっていたそうですが、やがて二羽が並び、写真のように恋人同 & 3.80 \\
& 士を思わせるしぐさに移ったそうです。 & \\
PB39_00009 & この町の子どもたちはまるで魚のように水と友だちだった。 & 3.67 \\
PB53_00056 & 荒海での厳しい操業を物語るかのように、片眼を失った船も一隻、しょんぼりと & 3.56 \\
& 岸壁上に体を横たえていた。 & \\
PN2a_00016 & 道路や公園を「養子」に、ボランティアを「里親」にみたてて清掃美化活動をす & 3.56 \\
& る。 & \\
\hline
\end{tabular}

25 分類語彙表番号 1.3721 資本・金銭：「C」は前場（前引け）や後場（大引け）の時刻にできた売買の值. 
人であることが関係しないため下位になると推測される.

表 20 に具体化の評定が上位の事例を示す.「メーク／ピカソ (の絵)」「噴火／噴水」「海に浮 かぶ様／一本の棒」「鉄船／巨大な壁」「内出血の赤さ／ペンキ」はいずれも喻辞が明確な視覚的 イメージを有している。そのようなイメージを被喻辞と重ね合わせることにより，被喻辞の具 体的な様態が受け手に伝わると推測される。「メーク／ピカソ」「海に浮かぶ様／一本の棒」は 比喻性判定の上位であり，「噴火／噴水」「鉄船／巨大な壁」はわかりやすさの判定の上位でも ある表現であり，比喻性とわかりやすさと具体化には関連が存在することが予測される.

表 21 に具体化の評定が下位の事例を示す。「口にする」が 4 例存在する。「Xにする」形式が 換喻的であり，積極的に表現対象を他の事物・事柄に見立てるものではないために具体化では ないと判断されたと推測される。「思い出したように」はある人物の話し方に対する表現主体の

表 19 擬人化の評定（下位事例）

\begin{tabular}{|c|c|c|}
\hline サンプル ID & 比喻事例 & 擬人化 \\
\hline PB35_00013 & $\begin{array}{l}\text { 「ここまでが標準仕様で、あとはオプションとなります」という言葉をよく耳に } \\
\text { しませんか？ }\end{array}$ & 0.44 \\
\hline PM26_00004 & $\begin{array}{l}\text { 最終的には円盤状病巣といわれる厚い線維性痏痕組織となり網膜機能は失われ } \\
\text { る。 }\end{array}$ & 0.44 \\
\hline OW6X_00073 & $\begin{array}{l}\text { タイ及びその周辺国への薬物分析技術の移転等を柱とする「薬物対策地域協力プ } \\
\text { ロジェクト」に、 }\end{array}$ & 0.48 \\
\hline PB1n_00024 & 午前十時四十分、議員バッジを 1 年半ぶりに胸にする加藤氏は言った。 & 0.50 \\
\hline PN3a_00017 & 火口だった場所は、すり鉢のように深くえぐれている。 & 0.50 \\
\hline
\end{tabular}

表 20 具体化の評定（上位事例）

\begin{tabular}{|c|c|c|}
\hline サンプル ID & 比喻事例 & 具体化 \\
\hline PM11_00260 & 化粧が天才的にへタでピカソみたいなメークになってる女や、 & 4.45 \\
\hline PB1n_00024 & 溶岩は、粘りが少ないため、噴火すると噴水のようにふきあがる。 & 4.35 \\
\hline PB39_00023 & 泳ぎつかれたら一本の棒みたいに海水に浮かび、 & 4.35 \\
\hline PB39_00009 & 大きな鉄船は巨大な壁のように目の前をふさいでいる。 & 4.23 \\
\hline OC09_03043 & 内出血の場合だとペンキをペタッと塗ったように真っ赤になります。 & 4.19 \\
\hline
\end{tabular}

表 21 具体化の評定（下位事例）

\begin{tabular}{l|l|r}
\hline サンプル ID & \multicolumn{1}{|c|}{ 比喻事例 } & 具体化 \\
\hline PB39_00010 & 漸く一言口にして、彼は絶句した。 & 1.09 \\
PM12_00014 & ダグは具体的なことをロにしなかった。 & 1.20 \\
PM21_00296 & 杉田がたまに思い出したようにそんな話をしても、(中略) 実際にはまともに & 1.25 \\
& 取り合わなくなっていた。 & \\
PM21_00296 & でも今は「やらせて下さい」と、無理にでもロにしている。 & 1.26 \\
OC09_04669 & しかも許すって言ったら2 度と口にしないのが鉄則です。 & 1.34 \\
\hline
\end{tabular}


印象を示すものであり，具体化しようとする例とは判断されない.

\subsection{2 クラウドソーシングによる評定值の統計分析}

以下では得られたクラウドソーシングデータに関して，例文のバイアスおよび実験協力者の バイアスを考慮した統計分析を行う。 rstan (Stan Development Team 2016) により，レジスタ による効果を分析するモデル (1) とレジスタ・種別による効果を分析するモデル (2) の線形混合 モデルを構築し，ベイズ推定する，具体的には，比喻性・新奇性・わかりやすさ・擬人化・具 体化の各パラメータを，提示文と実験協力者をランダム傾き（変量効果）としたうえで，レジ スタと種別を傾き（固定効果）として定義した次式によりモデル化する.

$$
y \sim \operatorname{Normal}(\mu, \sigma),
$$

$$
\begin{aligned}
& \mu \leftarrow \alpha+\beta_{\text {レジスタ }}^{O C} * \chi_{O C}(x)+\beta_{\text {レジスタ }}^{O W} * \chi_{O W}(x)+\beta_{\text {レジスタ }}^{O Y} * \chi_{O Y}(x)+\beta_{\text {レジスタ }}^{P B} * \chi_{P B}(x) \\
& +\beta_{\text {上ジスタ }}^{P M} * \chi_{P M}(x)+\beta_{\text {レジス夕 }}^{P N} * \chi_{P N}(x)+\gamma_{\text {例文 }}^{*}+\gamma_{\text {実験協力者 }}^{*} \\
& \text { (2) } \mu \leftarrow \alpha+\beta_{\text {レジスタ }}^{O C} * \chi_{O C}(x)+\beta_{\text {レジスタ }}^{O W} * \chi_{O W}(x)+\beta_{\text {レジスタ }}^{O Y} * \chi_{O Y}(x)+\beta_{\text {レジス夕 }}^{P B} * \chi_{P B}(x)
\end{aligned}
$$

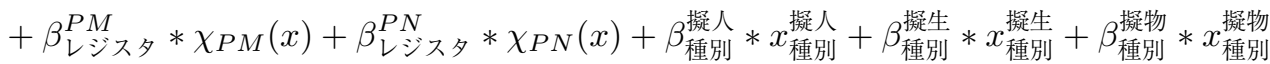

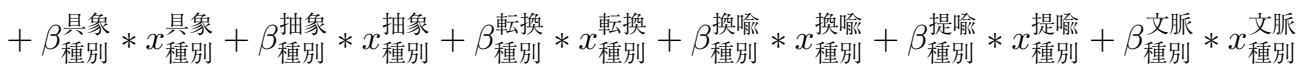

$$
\begin{aligned}
& +\beta_{\text {種別 }}^{\text {惯 }} * x_{\text {種別 }}^{\text {蝩別 }}+x_{\text {種別 }}^{\text {符他 }}+\gamma_{\text {例文 }}^{*}+\gamma_{\text {実験協力者 }}^{*}
\end{aligned}
$$

ここで, $y$ は比喻性・新奇性・わかりやすさ・擬人化・具体化の各パラメータとする（評定值 ごとに推定を行う). Normal は平均 $\mu$ 標準偏差 $\sigma$ の正規分布とし, 切片 $\alpha$ とレジスタ・種別に

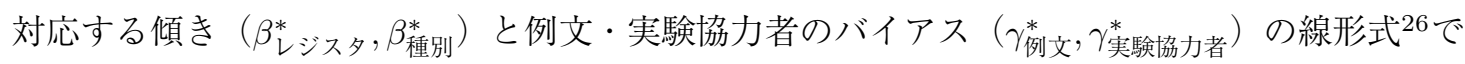
ある. 各変数の事前分布は標準正規分布とし, ハイパーパラメータ $\sigma$ も含めて, ベイズ推定 $(3$ chains, warmup 100, 1,000 iteration)を行う.

有効データポイント数は 27,072 , 提示文数 820 , 実験協力者数 1,164 であった. Gelman-Rubin 統計量 (Rhat) は 1.1 未満となっているときに，連鎖が定常状態に収束していると判断した。本 分析では，構築したいずれのモデルも収束した。なお，同等のモデルを頻度主義的な線形混合 モデル (lmer) により推定したところ収束しなかった。統計的な検討は事後平均 (mean) が事後 標準偏差 (sd) の 2 倍以上の差がある場合に, 強い証拠がある（以下の表中太字で示す）と判断 し，事後偏差の差がある場合に弱い証拠があると判断する ${ }^{27}$. 表 22,23 にレジス夕による効果 を分析するモデル (1) とレジスタ・種別による効果を分析するモデル (2) の結果を示す.

26 ここで $\chi_{A}(x):=\left\{\begin{array}{ll}1 & \text { if } x \in A \\ 0 & \text { if } x \notin A\end{array}\right.$ (そのレジスタか否かの指示関数), $x_{\text {種別 }}:=x$ 中の種別 $\mathrm{A}$ の結合の数とする.

27 本分析は帰無仮説に基づかないために，帰無仮説を前提とする有意差の議論は行わない.べイズ推定に基づく同様 の用語として「強い証拠 (strong evidence)」「弱い証拠 (weak evidence)」を用いる. 
表 22 統計分析結果：レジスタによる効果を分析するモデル (1)

\begin{tabular}{|c|c|c|c|c|c|c|c|c|c|c|}
\hline \multirow[b]{2}{*}{ Parameter } & \multicolumn{2}{|c|}{ 比喻性 } & \multicolumn{2}{|c|}{ 新奇性 } & \multicolumn{2}{|c|}{ わかりやすさ } & \multicolumn{2}{|c|}{ 擬人化 } & \multicolumn{2}{|c|}{ 具体化 } \\
\hline & mean & $\mathrm{sd}$ & mean & $\mathrm{sd}$ & mean & $\mathrm{sd}$ & mean & sd & mean & sd \\
\hline$\alpha$ & 2.45 & 0.39 & 1.88 & 0.40 & 2.97 & 0.40 & 1.40 & 0.39 & 2.76 & 0.44 \\
\hline$\beta_{\text {L }}^{O}$ & -0.13 & 0.44 & -0.24 & 0.43 & 0.21 & 0.42 & -0.02 & 0.44 & -0.12 & 0.47 \\
\hline$\beta_{\text {上ジス夕 }}^{O W}$ & -0.75 & 0.39 & -0.49 & 0.42 & -0.11 & 0.42 & -0.18 & 0.39 & -0.33 & 0.46 \\
\hline$\beta_{\text {レジス夕 }}^{O Y}$ & 0.32 & 0.41 & 0.12 & 0.42 & -0.03 & 0.40 & 0.09 & 0.41 & 0.00 & 0.45 \\
\hline$\beta_{\text {上ジス夕 }}^{P B}$ & 0.47 & 0.40 & 0.10 & 0.41 & 0.08 & 0.40 & 0.12 & 0.38 & 0.17 & 0.45 \\
\hline$\beta_{\text {レジス夕 }}^{P M}$ & 0.32 & 0.39 & 0.07 & 0.41 & 0.05 & 0.40 & -0.00 & 0.40 & 0.11 & 0.45 \\
\hline$\beta_{\text {レジス夕 }}^{P N}$ & 0.02 & 0.39 & -0.11 & 0.41 & 0.13 & 0.41 & -0.01 & 0.40 & 0.04 & 0.45 \\
\hline
\end{tabular}

表 23 統計分析結果：レジスタ・種別による効果を分析するモデル (2)

\begin{tabular}{|c|c|c|c|c|c|c|c|c|c|c|}
\hline \multirow[b]{2}{*}{ Parameter } & \multicolumn{2}{|c|}{ 比喻性 } & \multicolumn{2}{|c|}{ 新奇性 } & \multicolumn{2}{|c|}{ わかりやすさ } & \multicolumn{2}{|c|}{ 擬人化 } & \multicolumn{2}{|c|}{ 具体化 } \\
\hline & mean & sd & mean & sd & mean & $\mathrm{sd}$ & mean & $\mathrm{sd}$ & mean & $\mathrm{sd}$ \\
\hline$\alpha$ & 2.38 & 0.42 & 1.81 & 0.44 & 2.90 & 0.42 & 1.27 & 0.42 & 2.76 & 0.44 \\
\hline$\beta_{\text {レジス夕 }}^{O C}$ & 0.04 & 0.46 & -0.04 & 0.46 & 0.28 & 0.44 & 0.11 & 0.41 & -0.02 & 0.47 \\
\hline$\beta_{\text {上ジス夕 }}^{O W}$ & -0.45 & 0.45 & -0.27 & 0.45 & -0.05 & 0.43 & 0.02 & 0.43 & -0.19 & 0.42 \\
\hline$\beta_{\text {レジス夕 }}^{O Y}$ & 0.23 & 0.43 & 0.17 & 0.43 & -0.04 & 0.42 & 0.18 & 0.41 & -0.08 & 0.45 \\
\hline$\beta_{\text {レジスタ }}^{P B}$ & 0.22 & 0.42 & 0.10 & 0.43 & 0.05 & 0.42 & 0.12 & 0.41 & -0.01 & 0.43 \\
\hline$\beta_{\text {レジス夕 }}^{P M}$ & 0.15 & 0.42 & 0.12 & 0.43 & 0.03 & 0.42 & 0.08 & 0.41 & -0.03 & 0.44 \\
\hline$\beta_{\text {レ ジスタ }}^{P N}$ & -0.02 & 0.42 & -0.04 & 0.44 & 0.14 & 0.42 & 0.08 & 0.41 & -0.04 & 0.43 \\
\hline$\beta_{\text {擬人 }}$ 別 & 0.37 & 0.15 & 0.30 & 0.15 & 0.02 & 0.15 & 0.75 & 0.14 & 0.11 & 0.15 \\
\hline$\beta^{\text {擬告生 }}$ & 0.67 & 0.14 & 0.23 & 0.15 & 0.03 & 0.15 & 0.59 & 0.16 & 0.29 & 0.16 \\
\hline$\beta^{\text {畽物 }}$ & 0.46 & 0.15 & 0.25 & 0.14 & 0.10 & 0.15 & 0.41 & 0.14 & 0.19 & 0.16 \\
\hline$\beta_{\text {尰象 }}$ & 0.12 & 1.06 & 0.04 & 1.04 & -0.15 & 0.93 & 0.05 & 0.95 & -0.05 & 1.03 \\
\hline$\beta_{\text {秞揰別 }}$ & 0.46 & 0.51 & 0.36 & 0.52 & -0.17 & 0.49 & 0.13 & 0.49 & 0.34 & 0.51 \\
\hline$\beta_{\text {锺換 }}$ & 0.48 & 0.08 & 0.08 & 0.08 & 0.15 & 0.08 & 0.03 & 0.08 & 0.32 & 0.08 \\
\hline$\beta_{\text {揰險別 }}$ & -0.32 & 0.16 & 0.01 & 0.15 & -0.07 & 0.15 & -0.00 & 0.15 & -0.24 & 0.15 \\
\hline 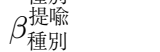 & 0.32 & 0.10 & 0.08 & 0.10 & 0.08 & 0.11 & -0.02 & 0.10 & 0.29 & 0.10 \\
\hline 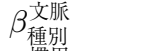 & -0.17 & 0.33 & 0.10 & 0.31 & -0.15 & 0.31 & 0.15 & 0.32 & -0.23 & -0.31 \\
\hline$\beta_{\text {慣闱別 }}$ & -0.72 & 0.10 & -0.36 & 0.10 & 0.05 & 0.10 & -0.20 & 0.11 & -0.45 & 0.10 \\
\hline$\beta_{\text {種別 }}^{\text {堂他 }}$ & 0.21 & 0.14 & -0.03 & 0.15 & 0.06 & 0.13 & 0.01 & 0.14 & 0.22 & 0.14 \\
\hline
\end{tabular}

まず，比喻性の結果について確認する。レジスタにおいては，レジスタの標準偏差が大きい ため, 白書 $(\mathrm{OW})$ の傾きが小さく，書籍 $(\mathrm{PB})$ の傾きが大きいという弱い証拠のみが確認され た，種別においては，擬人・擬生・擬物・転換・提喻の傾きが大きく，換喻・慣用の傾きが小 さいという強い証拠が確認された。 また，具象・抽象は標準偏差が大きい傾向が見られた. 
活喻（擬人化・擬生化）の場合, クラウドソーシングによる擬人化の評定とも関係するが, 比 喻性が高いと認識される傾向にあった，擬人化と対照的な擬物化も高く評定されており，人に 関わる比喻表現は，一般に比喻性が読み取られやすいといえよう。しかし，具象化の比喻性は 様々に判定されている，例を見ると，「研究の基盤」「時の流れ」「(以下の点を）柱とする・軸と する」のように，慣用的に用いられている表現が多く，これらは新奇性の評定とともに比喻性 の判定が低いためである。具象化は多くの結合類型例と頻度を有する分類であるからこそ，一 般的な表現であって比喻性を感じにくいともいえる。また，小規模な転換（その他の転換）は, 比喻性の高い傾向にあるが,「クレーターのようなくぼみ」のような例示に近い例や,「自転車 がバイクに似ている」のように喻辞と被喻辞の類似性が高いと考えられる結合例も含み, 例に よっては比喻性の判定に差が生じたようである，換喻は，「耳にする」「口にする」などで比喻 性が低く判定される傾向があり，比喻表現と認識されにくい例が多いようである，文脈比喻に ついては, 解釈に長い文脈を要する例もあり, 実験で表示された該当部分では比喻性が読み取 りにくかった影響も考えられる。

次に, 新奇性の結果について確認する。レジスタにおいては, 白書 $(\mathrm{OW})$ の傾きが小さいとい う弱い証拠のみが確認された，種別においては擬人の傾きが大きく，慣用の傾きが小さいとい う強い証拠が確認された。 また擬生・擬物・転換の傾きが大きいという弱い証拠が確認された. 比喻性が認識されやすい人を用いた表現（擬人・擬物）で新奇性が高く評定される傾向にあ る。慣用はその定義から新奇性が低いのは当然の結果であると言える。また，換喻は相対的に 傾きが小さい（事後平均 0.01）傾向にある. 換喻は一般に用いられている慣用的な表現が多い (「慣用」と重なりやすい) ため, 新奇な印象は得にくいものと考えられる，小規模な転換につ いては, 指標を必要として比喻性の把握を促すような表現では高く判定されるが, 比喻性が低 いと評定された喻辞と被喻辞の類似性が低い表現ではみとめられない傾向にあった。

わかりやすさにおいては, レジス夕間に特段の傾向は見られなかった．種別間は，転換の傾 きが大きいという弱い証拠が見られた。

指標を含む比喻用例は，概ねいくぶんかわかりやすいという印象で読まれているようである. 分類中, 慣用表現の評定が他分類よりも僅かに高く, 提喻や活喻など，一般に目にしやすいと 考えられる表現ほど，わかりやすいと判断される傾向がみられる．比喻表現がわかりやすさに 直結するというよりも，新奇でない目にしやすい表現がわかりやすいという判断につながって いる可能性もある.

擬人化の結果について検討する。まずレジスタにおいては特段の傾向は見られなかった．種 別においては，擬人・擬生・擬物の傾きが大きいという強い証拠が見られた。 また，慣用の傾 きが小さいという弱い証拠が見られた.

擬人化の用例で高い傾向がみられることは, 専門家の判断と一般の判断にそこまで摇れがな いということでもある. しかし，擬生化に分類された用例でも高く評定されている他，擬物化 
でも高めの評定となっている。喻辞が人に限らないとしても概ね生命に関する表現が含まれ， 結合としてわかりやすいためであろう（わかりやすさの結果を参照）。また，活喻については， 一般には，人と生命体（人には限定できない）を厳密に分類せず，生命活動であるという点に おいて読み手自らの身体性に鑑みるといえる。擬物化は，擬人化とは反対に人が被喻辞として 物に喻えられる例であるが, 擬物化も人を用いた比喻表現であるとの判断で, 人に喻えた例と 判断されたようである。なお，擬人化・擬生化・擬物化については，「子どもたちは魚のように 水と友だちだった」「次郎は舟と一体になる」のような重複ラベル用例も含んでいる.

具体化においては，レジスタ間の差異に特段の傾向は見られなかった。種別間では，転換の 傾きが大きく，慣用の傾きが小さいという強い証拠が見られた．また擬生・擬物・提喻・その 他の傾きが大きく，換喻の傾きが小さいという弱い証拠が見られた.

人に関わる用例において高く評定される傾向は，生命活動に関わる比喻表現が身体性として わかりやすく，具体的であると認識されるためであろう。また，標準偏差が大きいものの具象 化の用例は，具象化と判断されにくい傾向を示す結果となった．具象化の用例は，比喻性にお いても低い評定傾向であったことから，概念メタファー (Lakoff and Johnson 1980) として一般 的，かつ慣用的な用例が多いため，言語形式が比喻表現の把握を促していても，指標まで含め たイデイオム的な認識となり，具象化しているとあらためて認識されない可能性が高い.

\section{5 おわりに}

本研究では, 比喻の指標の可能性のある語句を手掛かりとし, BCCWJから比喻用例を収集し た. 手掛かりには 359 種類の指標とそれらの語義夕グも用い, 広く指標となり得る語句と語義を 含む網羅的な指標比喻の可能性を有する用例を収集している，指標比喻の可能性のある 97,118 用例から人手で 822 件を抽出し, 比喻情報のアノテーションを行った.

収集した用例と付与した情報により，指標比喻の特徵を確認した。種々の指標比喻を収集す る試みにより，たとえばいわゆる直喻において一般的な指標と考えられる「よう」が本データで は $43 \%$ にどまるなど, 指標要素が多様であることをはじめ, 指標比喻類型の分布傾向を見る ことができた。ささらに，比喻種別を分類すると，指標比喻においては，結合比喻に少ない「そ の他の転換」とまとめた小規模な転換の頻度が明らかに高いとわかった。喻辞と被喻辞がかけ 離れている大きなカテゴリーの転換（擬人化や具象化など）がある場合には，比喻性があきら かで指標が不要な場合が多く，小規模な転換であるゆえに言語形式で比喻性を示す傾向にある といえる，指標の有無は，比喻表現を構成する要素の概念マッピングの幅に関わっている可能 性が考えられる。 今後, 比喻表現の指標の有無による差異についても調査を進めたい.

また，クラウドソーシングによる比喻種別の分類から，観点の関係性が読み取れた。擬人化 や擬生化, 擬物化の評定結果など，専門知識を有する作業者と一般的な読み手間における認識差 
の影響が現れた観点もあるが，本調査で一般的な比喻認識が用例に付与されたことにより，明 らかになった差であるともいえる。但し，複数の表現（比喻的な要素の結合）が互いに影響し あっている可能性も考えられるため，今後は表現別に観点の評定を行う他，影響関係について も評定実験を考えている.

伊藤 (2014) は，比喻表現コーパスに望むこととして以下をあげている：

・一つのテクストを通して比喻のタグ付けをすること

・データとした談話やテクストは, 全文を閲覧可能であること

・データのメタ情報にアクセス可能なこと

・判断の摇れるものについては,できるだけ比喻であると認めること

・オープンであること

- 比喻の判断基準を明示すること

我々のデータは以上のいずれも満たす。 さらに, 中村 (1977) の文学作品中心の比喻用例データ ベースと異なり，Yahoo!知恵袋・白書・Yahoo!ブログ・書籍・雑誌・新聞の 6 レジスタを対象 として収集を行った。本データにより，文学作品以外にも比喻が多用されていることが確認で きた。

現在, 分類語彙表番号を意味情報として用いた, 結合比喻 (中村の第 2 類) パターンに基づく, 比 喻表現用例の収集も進めている (Kato and Asahara 2019). また, 語義や結合の認識の効率化のた めに, 文脈化単語埋め込み (Peters, Neumann, Iyyer, Gardner, Clark, Lee, and Zettlemoyer 2018) の利用を検討している。『国語研日本語ウェブコーパス』(Asahara, Maekawa, Imada, Kato, and Konishi 2014) から学習した自然言語処理の BERT (Devlin, Chang, Lee, and Toutanova 2019) モデルである NWJC-BERT (浅原, 西内, 加藤 2020) を構築し, BCCWJ に文脈化単語埋め込 み情報を付与した (浅原, 加藤 2020). 本研究で得られたデータと重ね合わせることで比喻情報 付き均衡コーパスのさらなる整備を進めたい.

\section{謝 辞}

本研究は, The International Cognitive Linguistic Conference (ICLC15) の発表 "Collecting Figurative Expressions Using Indicators and a Sementic Tagged Japanese Corpus" に基づくも のに，追加実験を行い，加筆修正をしたものです，本研究は，国立国語研究所コーパス開発セ ンター共同研究プロジェクト「コーパスアノテーションの拡張・統合・自動化に関する基礎研 究」によるものです。本研究の一部はJSPS 科研費 挑戦的研究（萌芽）18K18519, 基盤研究 (A) 17H00917, 新学術領域研究 $18 \mathrm{H} 05521$, 基盤研究 (C) 18K00634, 19K00591 の助成を受けたもの です。 


\section{参考文献}

浅原正幸, 加藤祥 (2020). BERTed-BCCWJ: 多層文脈化単語埋め込み情報を付与した『現代日本 語書き言葉均衡コーパス』データ. 言語処理学会第 26 回年次大会発表論文集, pp. 161-164. Asahara, M., Maekawa, K., Imada, M., Kato, S., and Konishi, H. (2014). "Archiving and Analysing Techniques of the Ultra-large-scale Web-based Corpus Project of NINJAL, Japan." Alexandria: The Journal of National and International Library and Information Issues, 25 (1-2), pp. 129-148.

浅原正幸, 西内沙恵, 加藤祥 (2020). NWJC-BERT: 多義語に対するヒトと文脈化単語埋め込み の類似性判断の対照分析. 言語処理学会第 26 回年次大会発表論文集, pp. 961-964.

Bowdle, B. F. and Gentner, D. (2005). "The Career of Metaphor." Psychological Review, 112, pp. 193-216.

Devlin, J., Chang, M.-W., Lee, K., and Toutanova, K. (2019). "BERT: Pre-training of Deep

Bidirectional Transformers for Language Understanding." In Proceedings of the 2019 Conference of the North American Chapter of the Association for Computational Linguistics: Human Language Technologies, Volume 1 (Long and Short Papers), pp. 4171-4186.

古谷望, 寺井あすか (2018). 参照表現利用に対する比喻の効果の検討. 言語処理学会第 24 回年

次大会発表論文集, pp. 200-203.

榛谷泰明 (1988). レトリカ一比喻表現辞典. 白水社.

伊藤薰 (2014). 比喻表現コーパスの構築と問題点一言語学の立場から一. 言語処理学会第 20 回 年次大会発表論文集, pp. 149-152.

神崎享子 (2013). 『複合動詞レキシコン』 ver.1一形態的・統語的・意味的情報付与一. 言語処 理学会第 19 回年次大会発表論文集, pp. 761-764.

Kato, S. and Asahara, M. (2019). "Exploring Metaphorical Expressions in Japanese NewspaperArticle Corpora." In International Cognitive Linguistics Conference 15.

加藤祥, 浅原正幸, 山崎誠 (2019a). 『現代日本語書き言葉均衡コーパス』新聞・書籍・雑誌デー 夕の助動詞に対する用法情報付与. 日本語学会 2019 年度春季大会予稿集, pp. 169-174.

加藤祥, 浅原正幸, 山崎誠 $(2019 b)$. 分類語彙表番号を付与した『現代日本語書き言葉均衡コー パス』の書籍・新聞・杂倠誌データ.日本語の研究, 15 (2), pp. 134-141.

菊地礼, 加藤祥, 浅原正幸 (2018). 「感じる」を指標とするメタファー用例の収集とその分析.

日本語用論学会メタファー研究会 2-Day シンポジウム「身体性」.

国立国語研究所 (編) (2004). 国立国語研究所資料集 14『分類語彙表一増補改訂版一』.大日本 図書.

近藤明日子, 田中牧郎 (2020). 「分類語彙表番号一UniDic 語彙素番号対応表」の構築. 国立国 
語研究所論集, pp. 77-91.

楠見孝 (1995). 比喻の処理過程と意味構造. 風間書房.

Lakoff, G. and Johnson, M. (1980). Metaphors We Live By. University of Chicago Press.

レイコフ・ジョージ，ジョンソン・マーク (1986). レトリックと人生. 渡部昇一, 楠瀬淳三, 下 谷和幸（訳）。大修館書店。

Maekawa, K., Yamazaki, M., Ogiso, T., Maruyama, T., Ogura, H., Kashino, W., Koiso, H., Yamaguchi, M., Tanaka, M., and Den, Y. (2014). "Balanced Corpus of Contemporary Written Japanese." Language Resources and Evaluation, 48, pp. 345-371.

宮島達夫 (1972). 動詞の意味 · 用法の記述的研究. 秀英出版.

宮澤涁, 吉田奈央, 宮尾祐介 (2016). 日本語メタファーコーパス作成のためのガイドライン. 言 語処理学会第 22 回年次大会発表論文集, pp. 150-153.

Nakamoto, K. (2003). "Semantic Priming Effect of Metaphor Constituent Terms." Perceptual and Motor Skills, 96, pp. 33-42.

中本敬子, 楠見孝 (2004). 比喻材料文の心理的特性と分類一基準表作成の試み一. 読書科学, 48 (1), pp. $1-10$.

中村明 (1977). 比喻表現の理論と分類. 国立国語研究所報告 57 . 秀英出版.

中村明 (1995). 比喻表現辞典. 角川書店.

中村明 (2007). 日本語の文体・レトリック辞典. 東京堂出版.

野内良三 (1998). 日本語の文体・レトリック辞典. 国書刊行会.

野内良三 (2005). 日本語修辞辞典. 国書刊行会.

Ortony, A., Vondruska, R. J., Foss, M. A., and Jones, L. E. (1985). "Salience, Similes, and the Asymmetry of Similarity." Journal of Memory and Language, 24, pp. 569-594.

Peters, M., Neumann, M., Iyyer, M., Gardner, M., Clark, C., Lee, K., and Zettlemoyer, L. (2018). "Deep Contextualized Word Representations." In Proceedings of the 2018 Conference of the North American Chapter of the Association for Computational Linguistics: Human Language Technologies, Volume 1 (Long Papers), pp. 2227-2237.

Pragglejaz Group (2007). "MIP: A Method for Identifying Metaphorically Used Words in Discourse." Metaphor and Symbol, 22 (1), pp. 1-39.

岡隆之介, 大島裕明，楠見孝 (2019). 比喻研究のための直喻刺激一解釈セット作成および妥当 性の検討. 心理学研究, 90 (1), pp. 53-62.

佐藤信夫, 佐々木健一, 松尾大 (2006). レトリック事典. 大修館書店.

Spanger, P. M., Yasuhara, M., Iida, R., and Tokunaga, T. (2012). "REX-J: Japanese Referring Expression Corpus of Situated Dialogs." Language Resources Evaluation, 46 (3), pp. $461-491$. 
Stan Development Team (2016). "RStan: the R interface to Stan." R package version 2.14.1.

Steen, G. J., Dorst, A. G., Herrmann, J. B., Kaal, A., Krennmayr, T., and Pasma, T. (2010). A Method for Linguistic Metaphor Identification. John Benjamins Publishing.

須堯大喜, 寺井あすか (2019). 係り受け解析を用いた比喻生成支援システム. 情報処理学会研究 報告 CH-119 No.1, pp. 1-6.

平知宏, 中本敬子, 楠見孝 (2007). 比喻理解における親しみやすさと解釈の多様性. 認知科学, 14 (3), pp. 323-338.

Utsumi, A. (2007). "Interpretive Diversity Explains Metaphor-simile Distinction." Metaphor and Symbol, 22, pp. 291-312.

山梨正明 (1988). 比喻と理解. 東京大学出版会.

山崎誠, 柏野和佳子 (2017). 『分類語彙表』の多義語に対する代表義情報アノテーション.言語 処理学会 第 23 回年次大会 発表論文集, pp. 302-305.

\section{略歴}

加藤 祥 : 2011 年神戸大学人文学研究科博士後期課程修了。 2012 年より国立 国語研究所コーパス開発センタープロジェクト PD フェロー。同プロジェク 卜非常勤研究員. 2020 年より目白大学外国語学部専任講師. 博士 (文学). 日 本語学会, 日本認知言語学会, 日本認知科学会各会員.

菊地礼：2018 年中央大学文学研究科博士課程前期修了. 同年より同大学博 士課程後期に在学.

浅原 正幸：2003 年奈良先端科学技術大学院大学情報科学研究博士後期課程修

了. 2004 年より同大学助教. 2012 年より人間文化研究機構国立国語研究所 コーパス開発センター特任准教授. 2019 年より同教授. 博士（工学)。言語 処理学会, 日本言語学会, 日本語学会各会員.

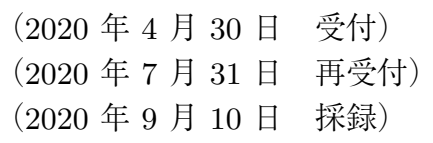

